\title{
The impact of stratospheric aerosol intervention on the North Atlantic and Quasi-Biennial Oscillations in the Geoengineering Model Intercomparison Project (GeoMIP) G6sulfur experiment
}

\author{
Andy Jones ${ }^{1}$, Jim M. Haywood ${ }^{1,2}$, Adam A. Scaife ${ }^{1,2}$, Olivier Boucher $^{3}$, Matthew Henry ${ }^{2}$, \\ Ben Kravitz ${ }^{4,5}$, Thibaut Lurton ${ }^{3}$, Pierre Nabat ${ }^{6}$, Ulrike Niemeier $^{7}$, Roland Séférian ${ }^{6}$, Simone Tilmes $^{8}$, \\ and Daniele Visioni ${ }^{9}$ \\ ${ }^{1}$ Met Office Hadley Centre, Exeter, UK \\ ${ }^{2}$ College of Engineering, Mathematics and Physical Sciences, University of Exeter, Exeter, UK \\ ${ }^{3}$ Institut Pierre-Simon Laplace, Sorbonne Université/CNRS, Paris, France \\ ${ }^{4}$ Department of Earth and Atmospheric Science, Indiana University, Bloomington, IN, USA \\ ${ }^{5}$ Atmospheric Sciences and Global Change Division, Pacific Northwest \\ National Laboratory, Richland, WA, USA \\ ${ }^{6}$ CNRM, Université de Toulouse, Météo-France, CNRS, Toulouse, France \\ ${ }^{7}$ Max Planck Institute for Meteorology, Hamburg, Germany \\ ${ }^{8}$ Atmospheric Chemistry, Observations and Modeling Laboratory, National Center for \\ Atmospheric Research, Boulder, CO, USA \\ ${ }^{9}$ Sibley School for Mechanical and Aerospace Engineering, Cornell University, Ithaca, NY, USA
}

Correspondence: Andy Jones (andy.jones@metoffice.gov.uk)

Received: 28 October 2021 - Discussion started: 9 November 2021

Revised: 12 January 2022 - Accepted: 13 January 2022 - Published: 7 March 2022

\begin{abstract}
As part of the Geoengineering Model Intercomparison Project a numerical experiment known as G6sulfur has been designed in which temperatures under a high-forcing future scenario (SSP5-8.5) are reduced to those under a medium-forcing scenario (SSP2-4.5) using the proposed geoengineering technique of stratospheric aerosol intervention (SAI). G6sulfur involves introducing sulfuric acid aerosol into the tropical stratosphere where it reflects incoming sunlight back to space, thus cooling the planet. Here, we compare the results from six Earth-system models that have performed the G6sulfur experiment and examine how SAI affects two important modes of natural variability, the northern wintertime North Atlantic Oscillation (NAO) and the Quasi-Biennial Oscillation (QBO). Although all models show that SAI is successful in reducing global mean temperature as designed, they are also consistent in showing that it forces an increasingly positive phase of the NAO as the injection rate increases over the course of the 21st century, exacerbating precipitation reductions over parts of southern Europe compared with SSP5-8.5. In contrast to the robust result for the NAO, there is less consistency for the impact on the QBO, but the results nevertheless indicate a risk that equatorial SAI could cause the QBO to stall and become locked in a phase with permanent westerly winds in the lower stratosphere.
\end{abstract}




\section{Introduction}

Global warming has accelerated swiftly over the last decade, with the last 7 years being warmer than any preceding years in the climatological record (e.g. https://climate.nasa.gov/ vital-signs/global-temperature/, last access: 17 June 2021). Climate model simulations suggest continued global warming throughout the next decades, irrespective of emissions associated with scenarios of future economic growth (known as shared socio-economic pathways, or SSPs; O'Neill et al., 2016). As a consequence, there is growing recognition that the global mean temperature targets of 1.5 and $2{ }^{\circ} \mathrm{C}$ above pre-industrial agreed at the Paris 21st Conference of Parties are going to be extremely difficult to achieve under conventional mitigation scenarios (e.g. Rogelj et al., 2016; Millar et al., 2017; IPCC, 2018; Tollefson, 2018). There is also a growing body of evidence that climate-induced damage frequently scales exponentially, rather than linearly, with temperature for metrics such as the frequency of extreme precipitation (Myhre et al., 2019), heatwaves (Christidis et al., 2015), droughts (Samaniego et al., 2018) and possibly tropical cyclones (Knutson et al., 2020). A further concern is that warming levels could be reached whereby key elements of the climate system such as the Amazon rainforest or the West Antarctic ice sheet could change dramatically in response to only a little additional warming (Lenton et al., 2019; Wunderling et al., 2021). These concerns have led to calls for research into less-conventional mitigation strategies (e.g. Royal Society, 2009; MacMartin et al., 2018; NAS, 2021). These include proposals to remove greenhouse gases from the atmosphere (frequently called carbon dioxide removal) and proposals to either block sunlight from reaching the planet or to increase the albedo of the planet to reflect more sunlight out to space (frequently called solar radiation management, SRM).

Among the most prominent of the proposed SRM strategies in the scientific literature is stratospheric aerosol intervention (SAI), which proposes injecting aerosols or their precursors into the stratosphere where their atmospheric lifetime is considerably extended compared with that in the troposphere and where the aerosols can reflect sunlight back to space, thereby cooling the planet (Royal Society, 2009; Lawrence et al., 2018; NAS, 2021). The injection material that has most frequently been studied is sulfur dioxide, in part because of work to understand and model the climatic impacts of large volcanic eruptions that periodically inject millions of tonnes of sulfur dioxide into the stratosphere. The resultant stratospheric sulfuric acid aerosol from both large eruptions such as that of Mount Pinatubo in 1991 and the combined impacts of numerous smaller eruptions that took place over the period 2005-2012 have been shown to cool the climate (e.g. Soden et al., 2002; Haywood et al., 2014; Santer et al., 2014; Schmidt et al., 2018).

Two important natural modes of variability in the atmosphere are the North Atlantic Oscillation (NAO; e.g. Hur- rell, 1995; Rodwell et al., 1999) and the Quasi-Biennial Oscillation (QBO; e.g. Lindzen and Holton, 1968; Baldwin et al., 2001). The NAO is defined by the anomaly in the mean sea level pressure (MSLP) between northern and sub-tropical regions of high variability in the Atlantic; locations in Iceland and the Azores are frequently used as these have the benefit of well-established long records of MSLP and are close to the centres of action of the dipolar NAO. The positive phase of the NAO is associated with an increase in the pressure gradient between the two regions, which is in turn associated with a strengthening of the jet-stream and a northward shift of the Atlantic storm track (e.g. Shindell et al., 2004). Zanardo et al. (2019) performed an observational analysis that showed that a positive phase of the NAO during Northern Hemisphere winter (defined throughout this study as December to February, DJF) clearly correlates with catastrophic flooding events in northern Europe. Similar positive precipitation anomalies were found in northern Europe during the positive phase of the NAO in DJF by López-Moreno and Vicente-Serrano (2008) and Casanueva et al. (2014), and higher levels of extreme precipitation were found by Scaife et al. (2008); the latter studies and Trigo et al. (2004) also report a concurrent reduction in precipitation in southern $\mathrm{Eu}-$ rope. There has been much debate as to whether aerosols from explosive volcanic eruptions that inject material into the stratosphere could cause warmer winters over Eurasia by affecting the NAO (e.g. Robock and Mao, 1992; Stenchikov et al., 2002; Fischer et al., 2007; Marshall et al., 2009). As well as absorbing outgoing terrestrial radiation, stratospheric aerosols absorb sunlight in the near infra-red region of the solar spectrum and also increase the mean photon path and therefore absorption of solar radiation in ozone-absorbing bands. In northern wintertime, this absorption leads to heating in the sunlit parts of the stratosphere at lower latitudes, thereby strengthening the temperature gradient and hence the polar vortex and inducing a positive phase of the NAO, increasing precipitation in northern Europe while decreasing it in southern Europe (Shindell et al., 2004; Scaife et al., 2008; Marshall et al., 2009). However, any induced positive anomaly in the NAO subsequent to volcanic eruptions was found to be under-represented in Coupled Model Intercomparison Project phase 5 models (Driscoll et al., 2012) and there are arguments that inter-annual variability dominated any induced response in a recent study of the 1991 Mount Pinatubo eruption (Polvani et al., 2019). Although there are differences between volcanic eruptions and SAI, the most obvious of which is that explosive volcanic eruptions are sporadic whereas SAI is most frequently modelled using continuous emissions, there are obvious similarities between them, and so two recent studies have examined the possible effects of SAI on the NAO. Jones et al. (2021) used ensembles of three simulations from two Earth-system models whereas Banerjee et al. (2021) used a 20-member ensemble from a single model; both concluded that SAI could induce a significant positive anomaly in the NAO. 
The QBO is characterised by downward-propagating easterly and westerly wind regimes in the equatorial stratosphere with a period of around 28 months (Baldwin et al., 2001) and is caused by the interaction of a broad spectrum of vertically propagating gravity waves with the mean flow (Lindzen and Holton, 1968). The reversal of the equatorial flow in the stratosphere is associated with larger-scale changes in the dynamics of the stratosphere and hence the transport of chemical species out of the tropical stratosphere to higher latitudes. The QBO also influences weather at the surface through its influence on the polar vortices, tropospheric jet-streams and storm-tracks (e.g. Holton, 1980; Kidston et al., 2015; Wang et al., 2018) and the phase of the QBO is known to influence the zonal and meridional transport of stratospheric volcanic aerosols from equatorial injections (e.g. Jones et al., 2016). Aquila et al. (2014) investigated the impact of equatorial stratospheric aerosol from SAI on the QBO and showed that progressively larger stratospheric sulfuric acid aerosol concentrations increased the period of the QBO and could, if of sufficient magnitude, cause the QBO to stall, resulting in a permanent westerly phase. Jones et al. (2016) examined the impacts of various aerosols as candidate SAI particles and found that those aerosols that absorbed more in the solar spectrum were the most effective at locking the QBO into a permanent westerly phase through their impacts on stratospheric temperatures.

The Geoengineering Model Intercomparison Project (GeoMIP) has been established for over a decade (Kravitz et al., 2011) and provides the most comprehensive multi-model assessment of the effects of SRM to date (e.g. Kravitz et al., 2013; Tilmes et al., 2013; Kravitz et al., 2021). In addition to several stand-alone model simulations (e.g. Tilmes et al., 2016; Jones et al., 2018), multi-model experiments with state-of-the-art climate models have progressed from relatively simple scenarios where the solar constant is reduced to offset an instantaneous quadrupling of carbon dioxide (e.g. Kravitz et al., 2013), to more policy-relevant experiments in the most recent phase of GeoMIP (Kravitz et al., 2015), which is aligned with the Coupled Model Intercomparison Project phase 6 (CMIP6; Eyring et al., 2016). In the GeoMIP experiment G6sulfur, simulated global mean temperature in a high-forcing scenario is reduced to the level of a medium-forcing scenario by the deployment of SAI geoengineering. The impacts on geographic temperature and precipitation distributions in these simulations have been shown to differ significantly from simulations that achieve the same global mean temperature goal simply by reducing the solar constant (Jones et al., 2021; Visioni et al., 2021).

This study extends the work of Jones et al. (2021) on the possible impact of SAI geoengineering on the NAO by using a wider range of GeoMIP models. We also investigate the effect of SAI on the QBO in these models to try to obtain a more general view of impacts than that provided by previous single-model studies. Section 2 provides a description of the experimental design, Sect. 3 presents the results and Sect. 4 a discussion and conclusions.

\section{Experiment Description}

The GeoMIP G6sulfur experiment is aimed at altering simulations based on ScenarioMIP high-forcing scenario SSP58.5 (O'Neill et al., 2016; experiment ssp585) to follow the evolution of medium-forcing scenario SSP2-4.5 (experiment ssp245) over the period 2020-2100 by including gradually increasing amounts of SAI in the G6sulfur simulations. The criterion for comparing the G6sulfur and ssp245 simulations was initially defined by Kravitz et al. (2015) in terms of radiative forcing, but this was subsequently altered to specify that the decadal global mean near-surface air temperatures of the two simulations should be the same to within $0.2^{\circ} \mathrm{C}$.

We examine the impact of SAI in the six models that have performed the G6sulfur simulations to date (Table 1); more information can be found in Visioni et al. (2021) and the references therein. Kravitz et al. (2015) were not prescriptive about how SAI should be implemented in the models as the details depend on each model's capabilities, resulting in different approaches that can be grouped into two basic categories. Three models injected $\mathrm{SO}_{2}$ into the stratosphere and then interactively modelled the subsequent gasand aerosol-phase processes: CESM2-WACCM injected $\mathrm{SO}_{2}$ on the Equator at the dateline at an altitude of $25 \mathrm{~km}$, whereas IPSL-CM6A-LR and UKESM1-0-LL followed the suggestion of Kravitz et al. (2015) and injected along a line from $10^{\circ} \mathrm{N}$ to $10^{\circ} \mathrm{S}$ on the Greenwich meridian at $18-20 \mathrm{~km}$. The other three models used prescribed aerosol optical depth (AOD) distributions: CNRM-ESM2-1 used a distribution provided by GeoMIP (from the G4SSA experiment; Tilmes et al., 2015), whereas MPI-ESM1-2-LR and MPI-ESM1-2HR used distributions from simulations detailed in Niemeier and Schmidt (2017) and Niemeier et al. (2020).

Kravitz et al. (2015) specified that the G6sulfur experiments should consist of a three-member ensemble, but not all models were able to provide three members; the ensemble size and realisation identifiers of the simulations available from each model are given in Table 1 . In the analyses presented here we have used only those ssp245 and ssp585 ensemble members that correspond to each model's G6sulfur ensemble members, even if there are more ensemble members available from the ssp245 or ssp585 experiments. The only exception is MPI-ESM1-2-HR, for which only two ensemble members are available for ssp245 and ssp585, but three from G6sulfur.

\section{Results}

Where the results for each model are presented separately we show the model's ensemble mean. Where multi-model means are presented, each model's ensemble mean was used to con- 
Table 1. The models used in this study with details of the experiment ensembles: the ensemble size, the identifiers of the individual simulations and the experiment data reference.

\begin{tabular}{|c|c|c|c|c|}
\hline Model & G6sulfur ensemble & ssp245 ensemble & ssp585 ensemble & G6solar ensemble \\
\hline $\begin{array}{l}\text { CESM2-WACCM } \\
\text { (Danabasoglu et al., 2020; } \\
\text { Gettelman et al., 2019) }\end{array}$ & $\begin{array}{l}\text { 2: r1i1p1f2, r1i1p1f2 } \\
\text { (Danabasoglu, 2019a) }\end{array}$ & $\begin{array}{l}\text { 2: r1i1p1f1, r2i1p1f1 } \\
\text { (Danabasoglu, 2019b) }\end{array}$ & $\begin{array}{l}\text { 2: r1ilp1f1, r2i1p1f1 } \\
\text { (Danabasoglu, 2019c) }\end{array}$ & $\begin{array}{l}\text { 2: rli1p1f1, r1i2p1f1 } \\
\text { (Danabasoglu, 2019d) }\end{array}$ \\
\hline $\begin{array}{l}\text { CNRM-ESM2-1 } \\
\text { (Séférian et al., 2019) }\end{array}$ & $\begin{array}{l}\text { 3: r1i1p1f2, r2ilp1f2, } \\
\text { r3i1p1f2 } \\
\text { (Séférian, 2019) }\end{array}$ & $\begin{array}{l}\text { 3: r1i1p1f2, r2ilp1f2, } \\
\text { r3i1p1f2 } \\
\text { (Voldoire, 2019a) }\end{array}$ & $\begin{array}{l}\text { 3: r1i1p1f2, r2ilp1f2, } \\
\text { r3i1p1f2 } \\
\text { (Voldoire, 2019b) }\end{array}$ & $\begin{array}{l}\text { 1: r1i1p1f2 } \\
\text { (Séférian, 2020) }\end{array}$ \\
\hline $\begin{array}{l}\text { IPSL-CM6A-LR } \\
\text { (Boucher et al., 2020a; } \\
\text { Lurton et al., 2020) }\end{array}$ & $\begin{array}{l}\text { 1: r1i1p1f1 } \\
\text { (Boucher et al., 2020b) }\end{array}$ & $\begin{array}{l}\text { 1: r1i1p1f1 } \\
\text { (Boucher et al., 2019a) }\end{array}$ & $\begin{array}{l}\text { 1: rli1p1f1 } \\
\text { (Boucher et al., 2019b) }\end{array}$ & $\begin{array}{l}\text { 1: r1i1p1f1 } \\
\text { (Boucher et al., 2019c) }\end{array}$ \\
\hline $\begin{array}{l}\text { MPI-ESM1-2-LR } \\
\text { (Müller et al., 2018) }\end{array}$ & $\begin{array}{l}\text { 3: r1i1p1f1, r2i1p1f1, } \\
\text { r3i1p1f1 } \\
\text { (Niemeier et al., 2019a) }\end{array}$ & $\begin{array}{l}\text { 3: r1i1p1f1, r2i1p1f1, } \\
\text { r3i1p1f1 } \\
\text { (Wieners et al., 2019a) }\end{array}$ & $\begin{array}{l}\text { 3: r1i1p1f1, r2i1p1f1, } \\
\text { r3i1p1f1 } \\
\text { (Wieners et al., 2019b) }\end{array}$ & $\begin{array}{l}\text { 3: r1i1p1f1, r2ilp1f1, } \\
\text { r3i1p1f } \\
\text { (Niemeier et al., 2019b) }\end{array}$ \\
\hline $\begin{array}{l}\text { MPI-ESM1-2-HR } \\
\text { (Müller et al., 2018) }\end{array}$ & $\begin{array}{l}\text { 3: r1i1p1f1, r2i1p1f1, } \\
\text { r3i1p1f1 } \\
\text { (Niemeier et al., 2019c) }\end{array}$ & $\begin{array}{l}\text { 2: r1i1p1f1, r2i1p1f1 } \\
\text { (Schupfner et al., 2019a) }\end{array}$ & $\begin{array}{l}\text { 2: r1i1p1f1, r2i1p1f1 } \\
\text { (Schupfner et al., 2019b) }\end{array}$ & $\begin{array}{l}\text { 3: r1i1p1f1, r2i1p1f1, } \\
\text { r3i1p1f1 } \\
\text { (Niemeier et al., 2019d) }\end{array}$ \\
\hline $\begin{array}{l}\text { UKESM1-0-LL } \\
\text { (Sellar et al., 2019) }\end{array}$ & $\begin{array}{l}\text { 3: r1i1p1f2, r4i1p1f2, } \\
\text { r8ilp1f2 } \\
\text { (Jones, 2019a) }\end{array}$ & $\begin{array}{l}\text { 3: r1i1p1f2, r4i1p1f2, } \\
\text { r8ilp1f2 } \\
\text { (Good et al., 2019a) }\end{array}$ & $\begin{array}{l}\text { 3: r1i1p1f2, r4i1p1f2, } \\
\text { r8ilp1f2 } \\
\text { (Good et al., 2019b) }\end{array}$ & $\begin{array}{l}\text { 3: r1ilp1f2, r4i1p1f2, } \\
\text { r8ilp1f2 } \\
\text { (Jones, 2019b) }\end{array}$ \\
\hline
\end{tabular}

struct the multi-model mean and the data were re-gridded to the resolution of the highest resolution model (MPI-ESM12-HR) before averaging.

\subsection{SAI Cooling}

All models were successful in reducing the global mean temperatures in the G6sulfur simulations from the levels of ssp585 to within $0.2^{\circ} \mathrm{C}$ of those in ssp245 (see Visioni et al., 2021 for details). Figure 1 shows each model's 20812100 ensemble mean difference in near-surface air temperature between G6sulfur and ssp585, indicating the amount of cooling required from SAI in the different models. There is considerable spread, with one group (CNRM-ESM2-1, MPIESM1-2-LR and MPI-ESM1-2-HR) requiring a temperature reduction of $\sim 1.5^{\circ} \mathrm{C}$ to cool ssp585 to ssp245 levels by the end of the century, whereas the other group (CESM2WACCM, IPSL-CM6A-LR and UKESM1-0-LL) requires a temperature reduction of $\sim 2.5^{\circ} \mathrm{C}$ by the end of the century. This demonstrates that, as well as differences in the way the models simulate the impacts of SAI, there are also considerable differences in the models' climate sensitivities and thus in the amount of warming they produce under a given scenario, often tied to their representation of clouds and how they respond in the future (Zelinka et al., 2020).

\subsection{Impact on the NAO}

Here, we follow the approach of Stephenson et al. (2006) and Baker et al. (2018) in defining the boreal wintertime
$\mathrm{NAO}$ as the mean DJF difference in area mean sea-level pressure between two regions: one bounded by $90^{\circ} \mathrm{W}-60^{\circ} \mathrm{E}$, $20-55^{\circ} \mathrm{N}$, the other by $90^{\circ} \mathrm{W}-60^{\circ} \mathrm{E}, 55-90^{\circ} \mathrm{N}$. We use this definition of the NAO for its simplicity, but our conclusions are not affected by the use of a more complex NAO definition (e.g. Tsanis and Tapoglou, 2019; Hurrell et al., 2020). The evolution of this pressure difference in the six models for ssp245 and G6sulfur is shown in Fig. 2; note that the $y$-axis range $(10 \mathrm{hPa})$ is the same for all models even though the absolute values differ. Despite considerable variability, all models agree in showing little systematic change in this measure of the NAO in ssp245 over the 2021-2100 period, the multi-model mean gradient of the straight-line fit being $+0.02 \mathrm{hPa}$ per decade (range -0.03 to $+0.16 \mathrm{hPa}$ per decade). In contrast, all models in G6sulfur exhibit a positive trend in the pressure difference, with a multi-model mean gradient of $+0.63 \mathrm{hPa}$ per decade (range +0.37 to $+1.11 \mathrm{hPa}$ per decade). The ranges of the slopes from the two sets of simulations do not overlap, clearly showing that G6sulfur, though maintaining global mean temperature at the same level as ssp245, also causes the wintertime NAO to become increasingly more positive throughout the century. However, the inclusion of SAI is obviously not the only difference between G6sulfur and ssp245. G6sulfur also includes the higher levels of greenhouse gases (GHGs) and other changes in the ssp585 experiment whose warming effects the SAI is designed to offset. In order to assess whether the NAO changes seen in G6sulfur are due to SAI, the results from G6sulfur need to be compared against those from a simi- 

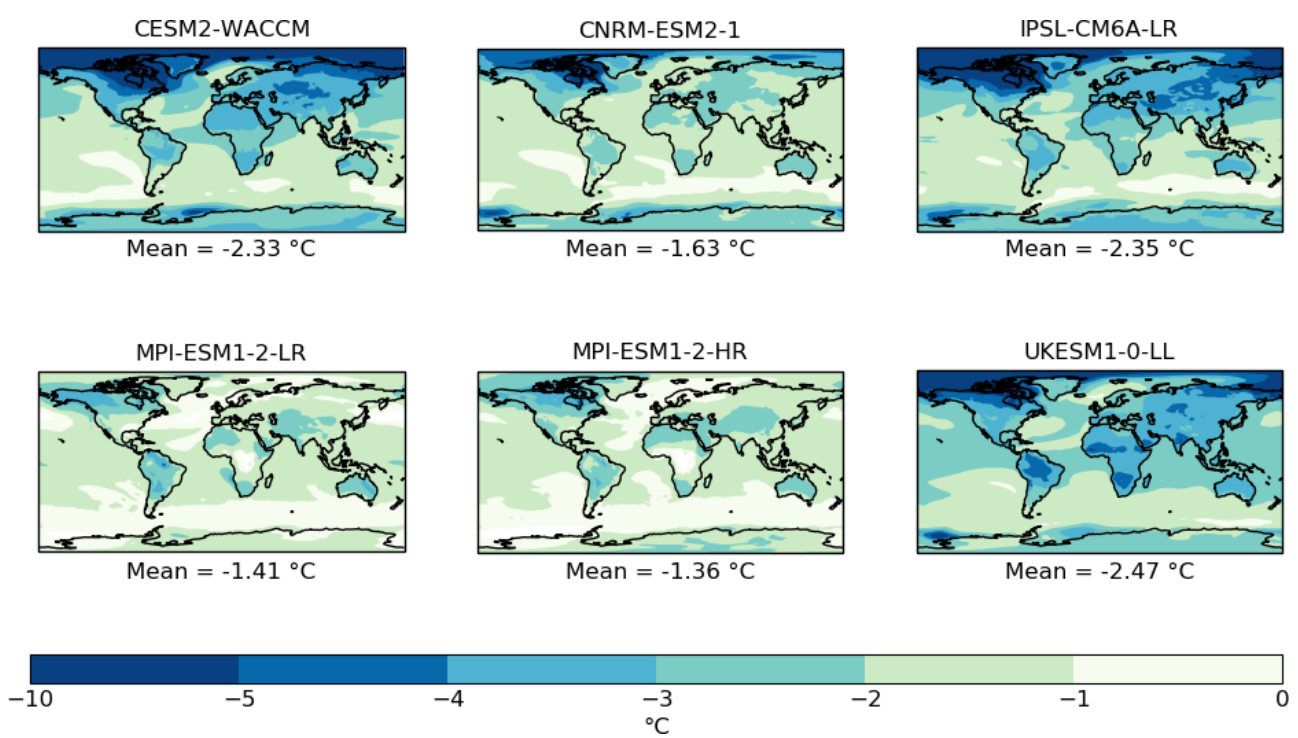

Figure 1. G6sulfur minus ssp585 difference in 2081-2100 annual mean near-surface air temperature $\left({ }^{\circ} \mathrm{C}\right)$ for each model; all results are ensemble means.

lar experiment that does not include SAI and that also follows the same temperature evolution as G6sulfur, thus ruling out a straightforward comparison against ssp585. The latter condition is required because studies of scenarios with warming levels similar to ssp585 have been found to affect the NAO (e.g. Tsanis and Tapoglou, 2019). Both conditions are satisfied by the GeoMIP experiment G6solar (Kravitz et al., 2015), which is parallel to G6sulfur but achieves the cooling from ssp585 to ssp245 levels by the highly idealised method of reducing the specified solar output. The multimodel mean NAO gradient of the G6solar simulations from the models used here is $-0.04 \mathrm{hPa}$ per decade (range -0.20 to $+0.13 \mathrm{hPa}$ per decade), which is similar to the gradient in ssp245, supporting the conjecture that SAI is responsible for the change in the NAO in G6sulfur. For reference, the multi-model mean gradient in ssp585 is $+0.30 \mathrm{hPa}$ per decade (range -0.22 to $+0.86 \mathrm{hPa}$ per decade).

The distributions of Northern Hemisphere DJF mean temperature differences between G6sulfur and ssp245 for 20812100 are shown in Fig. 3. Although they vary in degree, all models show clear warming over northern Eurasia consistent with the positive NAO anomaly (Hurrell, 1995; Shindell et al., 2004), although the warming is still less than in ssp585. They also show cooling over the Labrador Sea and warming over the eastern USA, again as expected from a long-term positive shift in the NAO (Scaife et al., 2005); however, the picture is less consistent for differences over North America (Banerjee et al., 2021; Jones et al., 2021). The corresponding differences in Northern Hemisphere wintertime precipitation are shown in Fig. 4. The models are consistent in showing increases in precipitation in northern Europe and reductions in southern Europe as observed for a positive phase of the NAO (Trigo et al., 2004; Scaife et al., 2008; Casanueva et al., 2014), but the boundary between these two regimes varies model to model; as with temperature, there is less consistency over North America. Figure 5 shows the multimodel mean difference in 2081-2100 mean DJF temperature and the land precipitation rate between G6sulfur and ssp245. Multi-model means are frequently found to be a better representation of reality than a single model (Tebaldi and Knutti, 2007; Christiansen, 2018) and suggests that the forced positive phase of the wintertime NAO indicated in G6sulfur is a robust result.

The comparisons presented so far represent the differences between two possible worlds with the same global mean temperature (that of the end of the century under scenario SSP2-4.5) but in which one world uses SAI (G6sulfur) and the other does not (ssp245). We now examine temperature and precipitation over Europe to compare changes from the present day under scenario SSP5-8.5 plus SAI (i.e. G6sulfur) with the situations under scenarios SSP2-4.5 and SSP5-8.5. Figure 6a shows the multi-model mean difference in DJF mean surface air temperature between the end of the century in ssp245 (mean over 2081-2100) and the present-day (mean over 2011-2030), which shows a typical pattern of increased warming at higher latitudes and over land. As expected, this warming is greater in ssp585 (Fig. 6b) and the latter is then somewhat reduced in G6sulfur (Fig. 6c) while also showing the impact of the change in the NAO. Figure $6 \mathrm{~d}-\mathrm{f}$ shows the corresponding multi-model mean differences in DJF mean land precipitation rate. In ssp245 (Fig. 6d) there is a general increase in precipitation over most of central and northern Europe and a slight reduction over southern Europe; these changes are amplified in the high-emissions ssp585 experiment (Fig. 6e). The use of SAI in G6sulfur ameliorates the increase in precipitation over northern $\mathrm{Eu}$ - 

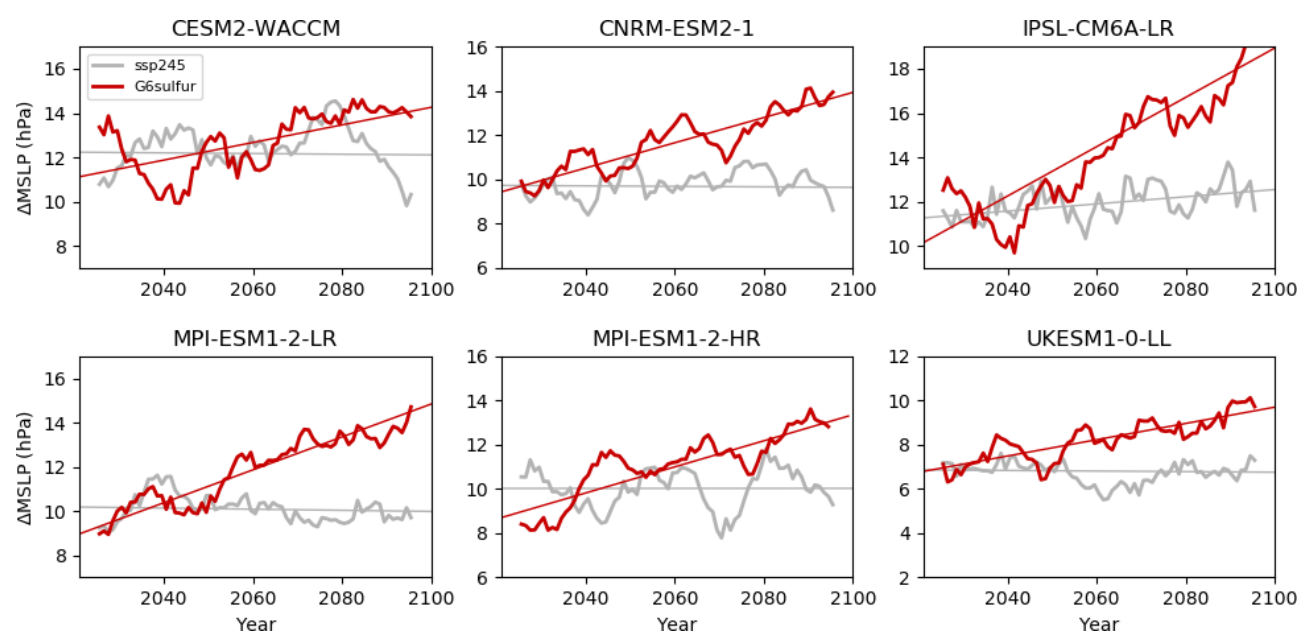

Figure 2. Evolution of the North Atlantic Oscillation, defined as the December to February mean sea-level pressure difference between regions bounded by $90^{\circ} \mathrm{W}-60^{\circ} \mathrm{E}, 20-55^{\circ} \mathrm{N}$ and $90^{\circ} \mathrm{W}-60^{\circ} \mathrm{E}, 55-90^{\circ} \mathrm{N}(\mathrm{hPa}$ ), for each model in experiments ssp245 (grey) and G6sulfur (red). All results are ensemble means and have been smoothed using a 10-year running mean; a least-squares straight line fit to each is also plotted.
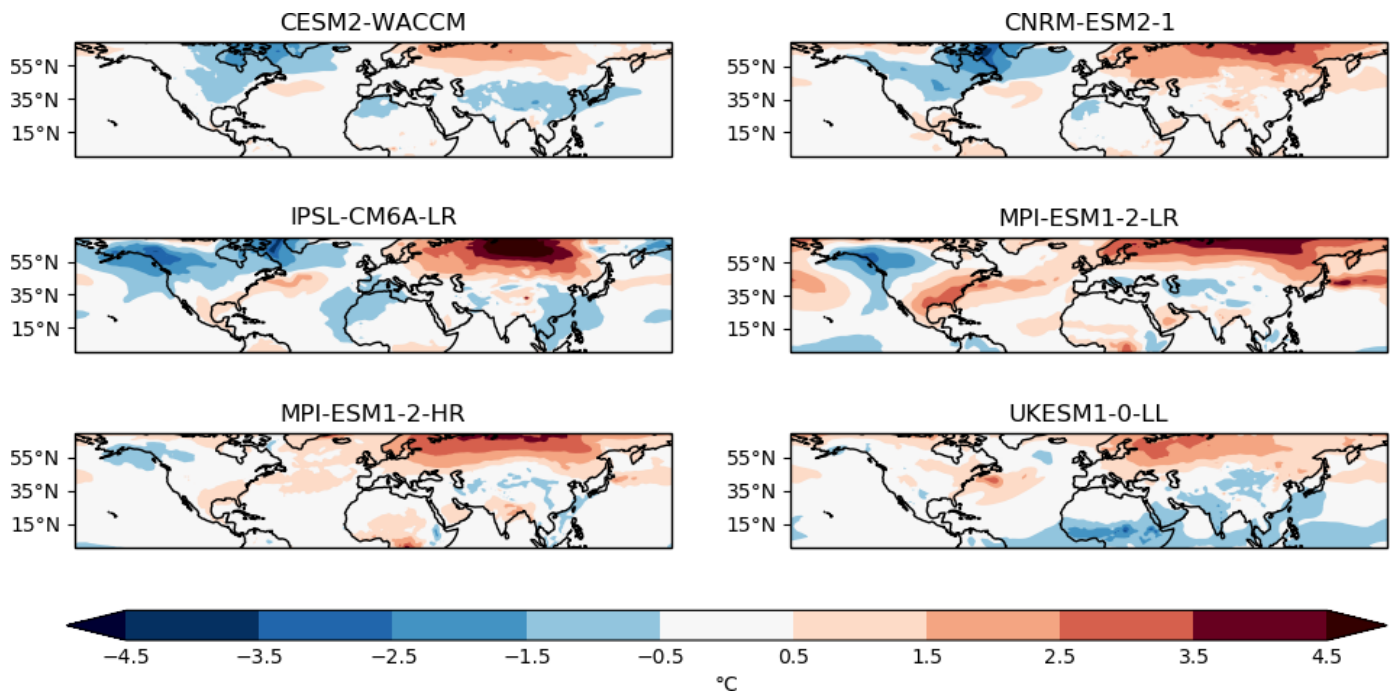

Figure 3. G6sulfur minus ssp245 difference in 2081-2100 mean December to February near-surface air temperature $\left({ }^{\circ} \mathrm{C}\right)$ for each model. The area plotted replicates that presented by Jones et al. (2021; their Fig. 8) to concentrate on the area affected by the NAO.

rope that occurs in ssp585 while exacerbating the reduction in precipitation over southern Europe (Fig. 6f). This reduction is especially marked over the Iberian Peninsula where the multi-model mean wintertime precipitation is reduced by $6.7 \%$ in ssp585 but by $22.3 \%$ in G6sulfur compared with the present day, with corresponding reductions of $11.1 \%$ and $29.1 \%$ in precipitation-minus-evaporation. This would be of great concern given the projected strong drying trend and water scarcity in this region (e.g. Molina et al., 2020; PerkinsKirkpatrick and Lewis, 2020). So although G6sulfur is successful at maintaining global mean temperature at ssp245 levels despite ssp585 levels of GHGs, the changes in Euro- pean precipitation from the present are clearly not maintained at ssp245 levels.

\subsection{Impact on the QBO}

The impact of SAI on the QBO in single or pairs of models has been studied for a number of years (e.g. Aquila et al., 2014; Jones et al., 2016; Richter et al., 2017; Tilmes et al., 2018a; Niemeier et al., 2020; Franke et al., 2021). These studies indicate that heating of the lower stratosphere by SAI aerosols is the main factor impacting the QBO, with sufficient SAI affecting the thermal wind balance causing the QBO to stall and locking it into a permanent westerly phase 

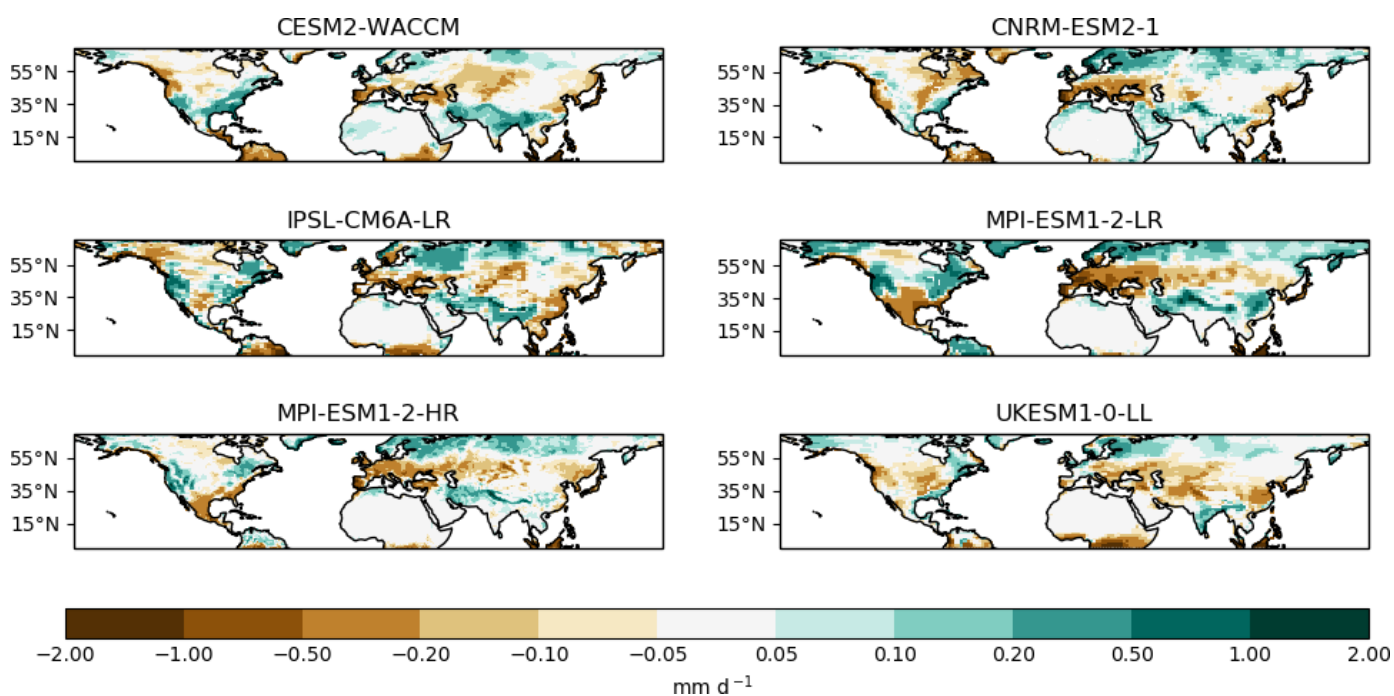

Figure 4. As Fig. 3 but for land precipitation rate $\left(\mathrm{mm} \mathrm{d}^{-1}\right)$.
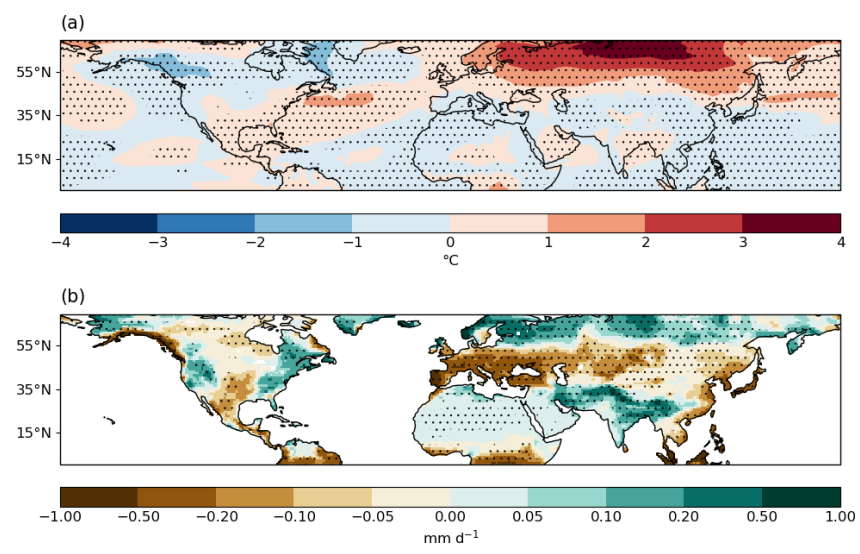

Figure 5. Multi-model mean difference in 2081-2100 December to February near-surface air temperature $\left({ }^{\circ} \mathrm{C}, \mathbf{a}\right)$ and land precipitation rate $\left(\mathrm{mm} \mathrm{d}^{-1}, \mathbf{b}\right)$ between $\mathrm{G} 6$ sulfur and ssp245. Areas where the difference is significant at the $5 \%$ level in a two-tailed $t$ test are stippled.

(Aquila et al., 2014; Jones et al., 2016; Franke et al., 2021). Note that throughout this study we define the phase of the QBO as the direction of the zonal mean equatorial winds at $30 \mathrm{hPa}$. The amount of SAI required to cause the QBO to shut down has been shown to be model dependent: it is affected by a model's handling of aerosol and aerosol-radiation interactions and also by the treatment of stratospheric dynamics, which affects the model's vertical advection (Niemeier et al., 2020). Both Richter et al. (2017) and Franke et al. (2021) have shown that the geographic location of the SAI is of crucial importance in the response of the QBO. Richter et al. (2017) found that moving the SAI location away from the Equator made the QBO period decrease in their model, whereas Franke et al. (2021) found that an amount of SAI that caused the simulated QBO to shut down when applied at the Equator had much less of an effect when applied instead at $30^{\circ} \mathrm{N}$ and $30^{\circ} \mathrm{S}$.

When examining the impact of SAI on the QBO in G6sulfur it is instructive to know how well the different models simulate the QBO in the absence of SAI in ssp245. Figure $7 \mathrm{a}-\mathrm{f}$ shows the stratospheric zonal wind averaged between $5^{\circ} \mathrm{S}$ and $5^{\circ} \mathrm{N}$ from the first ensemble member (simulation identifier beginning " $r 1$ " in Table 1) of each model's ssp245 ensemble over the period 2020-2099 (both MPIESM1-2-LR and MPI-ESM1-2-HR's r1 simulations lack data for 2100 in G6sulfur so this year is also omitted here). All but one of the models are able to simulate a QBO but there are various deficiencies in the simulations, especially in relation to the amplitude of the QBO between $\sim 20$ and $\sim 100 \mathrm{hPa}$, issues that have been present since the first general circulation model simulations of the QBO (Scaife et al., 2000; Giorgetta et al., 2002) and continue in CMIP6 models (Richter et al., 2020). The evolution of stratospheric winds in the models may be compared with those from the ERA5 reanalyses shown in Fig. 7g (Hersbach et al., 2019); Table 2 summarises the performance of each model in simulating the QBO when compared with ERA5. Figure 7 also shows that there are no obvious changes in the QBO over the course of the century in ssp245 and certainly no sign of the QBO shutting down in the absence of SAI, despite rare disruptions to its regular cycling (e.g. Osprey et al., 2016).

Figure 8 shows the stratospheric winds from the first ensemble member (r1) of each model's G6sulfur simulation. A single ensemble member is plotted rather than an ensemble mean, as any QBO shutdown is likely to be a discrete event at a given point in time and it is not meaningful to average across an ensemble whose members may simulate this process at different times. Of the five models that simu- 

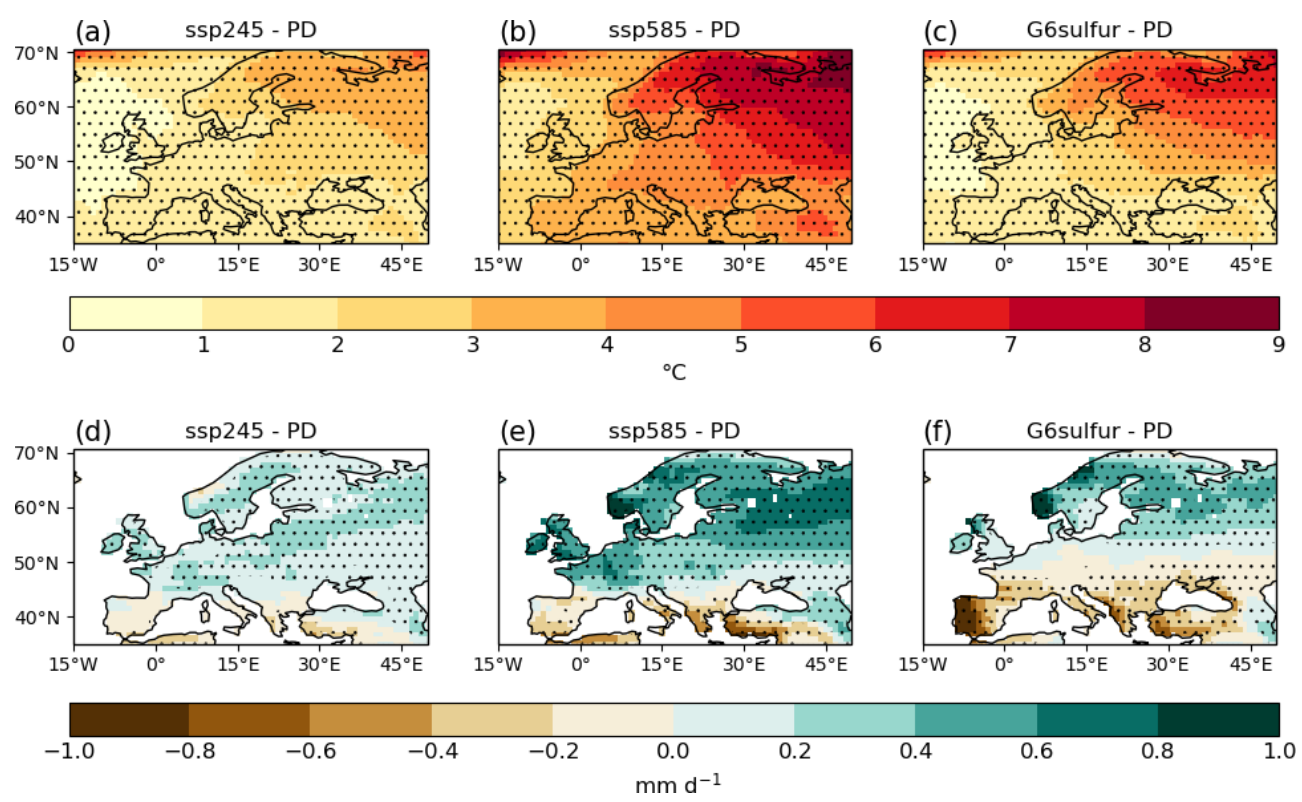

Figure 6. Multi-model mean difference in December to February (DJF) mean near-surface air temperature $\left({ }^{\circ} \mathrm{C}\right)$ between ssp245 $(2081-$ 2100) and the present day (PD; 2011-2030) (a). Same as (a) but for the difference between ssp585 and PD (b). Same as (a) but for the difference between G6sulfur and PD (c). Multi-model mean difference in DJF land precipitation rate ( $\mathrm{mm} \mathrm{d}^{-1}$ ) between ssp245 and PD (d). Same as (d) but for the difference between ssp585 and PD (e). Same as (d) but for the difference between G6sulfur and PD (f). The PD data comprise years 2011-2014 from the CMIP6 historical simulations and years 2015-2030 from the corresponding ssp245 simulations. Areas where the difference is significant at the $5 \%$ level in a two-tailed $t$ test are stippled.

Table 2. The QBO period and a qualitative summary of the QBO simulation in ssp245 by each model's r1 ensemble member (Fig. 7a-f) based on a comparison with ERA5 (Fig. 7g). The QBO period is estimated from the number of easterly-to-westerly zonal wind transitions at $30 \mathrm{hPa}$ during 2020-2099.

\begin{tabular}{|c|c|c|}
\hline Model & QBO period (months) & Comment \\
\hline CESM2-WACCM & 16 & $\begin{array}{l}\text { Period too short. Westerlies do not penetrate far enough downwards, ending at } \\
\sim 40 \mathrm{hPa} \text { when the ERA5 data show them reaching down to } 100 \mathrm{hPa} \text {. }\end{array}$ \\
\hline CNRM-ESM2-1 & 17 & $\begin{array}{l}\text { Period too short. Westerlies terminate at } \sim 60 \mathrm{hPa} \text { and the descent is too uniform } \\
\text { (no stalling of the transition from westerlies to easterlies at } \sim 40 \mathrm{hPa} \text { ). }\end{array}$ \\
\hline IPSL-CM6A-LR & 25 & $\begin{array}{l}\text { Westerlies do not reach } 100 \mathrm{hPa} \text {. There is also a lot of westerly activity at } \\
\sim 10 \mathrm{hPa} \text { that is not seen in ERA5. }\end{array}$ \\
\hline MPI-ESM1-2-LR & $\mathrm{n} / \mathrm{a}$ & No QBO-like periodicity present. \\
\hline MPI-ESM1-2-HR & 29 & $\begin{array}{l}\text { Westerlies do not penetrate to } 100 \mathrm{hPa} \text {. There are also long periods of westerly } \\
\text { winds at } \sim 10 \mathrm{hPa} \text { that are not evident in ERA5. }\end{array}$ \\
\hline UKESM1-0-LL & 29 & Duration of westerlies below $\sim 40 \mathrm{hPa}$ is rather too long. \\
\hline
\end{tabular}

n/a: not applicable.

late QBO-like behaviour in their ssp245 simulations, three (IPSL-CM6A-LR, MPI-ESM1-2-HR and UKESM1-0-LL) clearly show a shutting down of the QBO when SAI is applied, resulting in persistent westerlies in the lower stratosphere by the end of the century. The tendency towards permanent westerlies is also evident in MPI-ESM1-2-LR, even though this model shows no QBO-like periodicity in either ssp245 or G6sulfur. In contrast, two models (CESM2-
WACCM and CNRM-ESM2-1) do not show such behaviour, with alternating easterly and westerly winds continuing until the end of the century in these models. There is no correlation between simulating a QBO shutdown and the method of implementing SAI: two models that use $\mathrm{SO}_{2}$ injection simulate a shutdown whereas one does not, and similarly with those using prescribed AOD distributions. Although the altitude of $\mathrm{SO}_{2}$ injection can affect the radiative impact of 

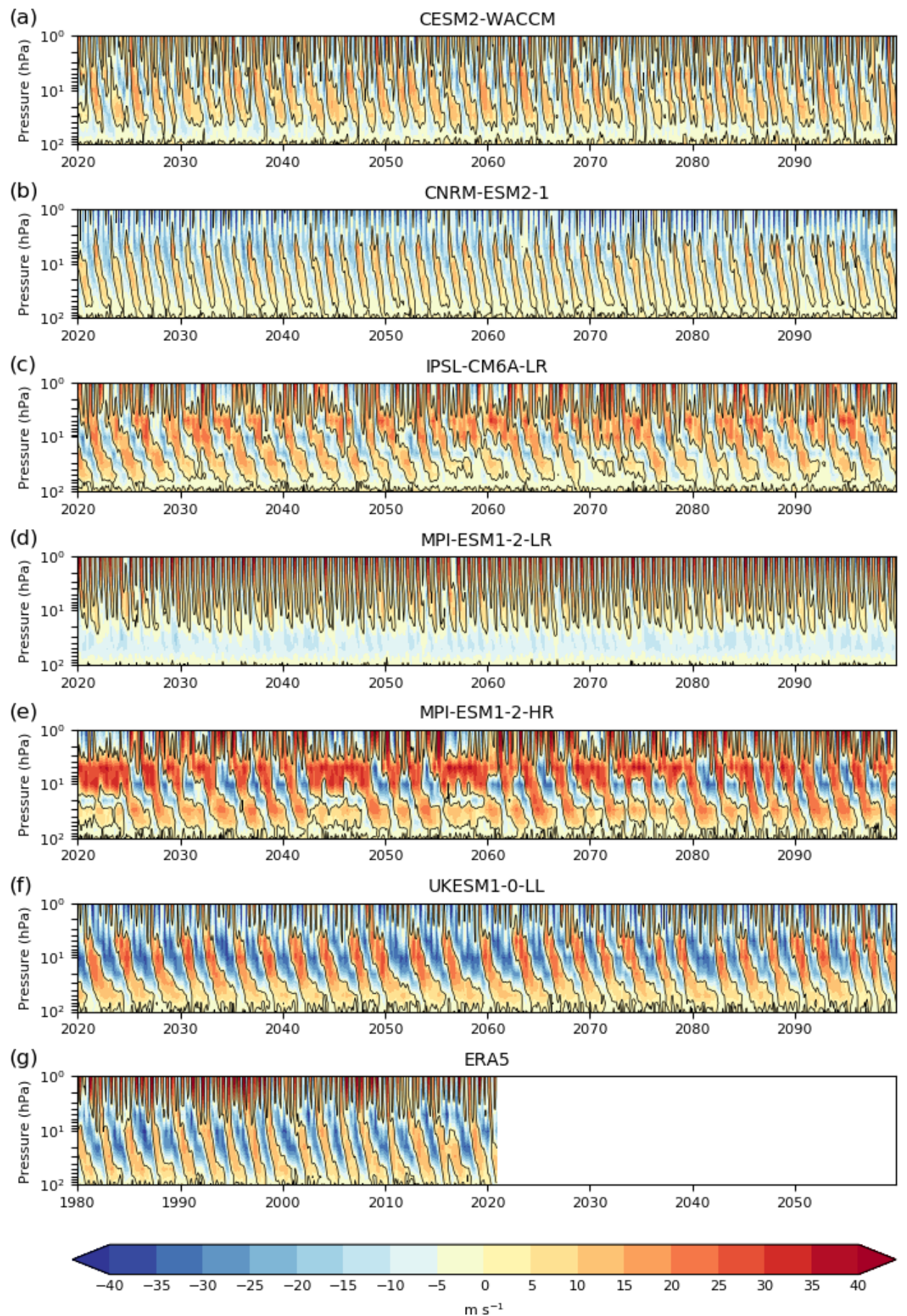

Figure 7. Time-pressure cross-sections of $5^{\circ} \mathrm{N}-5^{\circ} \mathrm{S}$ mean zonal stratospheric winds $\left(\mathrm{m} \mathrm{s}^{-1}\right)$ from the first ensemble member of each model's ssp245 simulation (a-f) and using ERA5 data (g). The ERA5 plot was generated using Copernicus Climate Change Service information (Hersbach et al., 2019). Positive values indicate westerly winds and negative values indicate easterlies; the black contour is at $0 \mathrm{~m} \mathrm{~s}{ }^{-1}$.

SAI (e.g. Niemeier et al., 2011), there is no correlation between the amount of stratospheric warming induced by SAI and the shutting down of the QBO: for example, the QBO in MPI-ESM1-2-HR r1 shuts down at the start of the 2030s with a maximum zonal mean stratospheric warming of $3.1^{\circ} \mathrm{C}$ (mean over 2031-2040) compared with ssp245, whereas the QBO in CESM2-WACCM r1 is still present at the end of the century, with warming of $8.8^{\circ} \mathrm{C}$ (mean over 2091-2100). The onset of QBO shutdown in those models in which it occurs is also very variable, with dates ranging from $\sim 2030$ to 

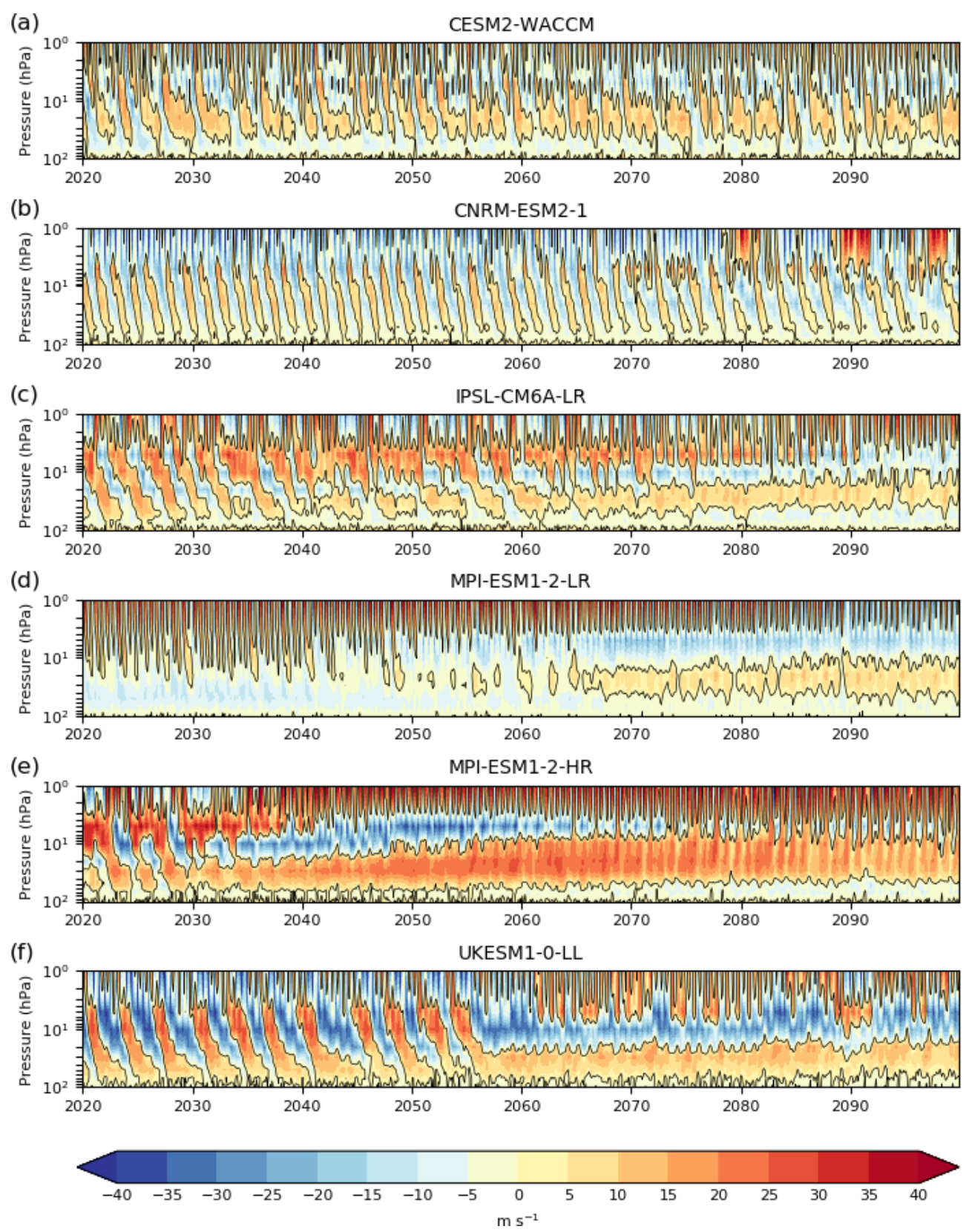

Figure 8. Same as Fig. 7a-f but from the first ensemble member of each model's G6sulfur simulation.

2060-2070. Similar behaviour is seen in the other ensemble members (not shown) with only slight variation in the timing of any QBO shutdown. It is not the purpose of this study to enter into an examination of the ability or otherwise of these models to accurately simulate the QBO or an analysis of why it shuts down in some models under SAI. Rather it is to demonstrate that there is no consistent guidance from these state-of-the-art climate models, even in a well-defined experiment such as G6sulfur, as to the impact of SAI on the QBO. Nevertheless, despite the lack of consistency, these re- sults suggest that there might be a significant risk that the form of SAI examined here could terminate the QBO.

One of the possible effects of a shutdown of the QBO and the resulting persistent westerly phase is related to the fact that transport of material out of the tropical lower stratosphere is modulated by the phase of the QBO and is reduced during the westerly phase (Punge et al., 2009; Visioni et al., 2018). Consequently, it is possible that a persistent westerly phase would lead to reduced transport of SAI aerosol out of the equatorial region. There may also be a slight counteracting effect whereby increased confinement of 


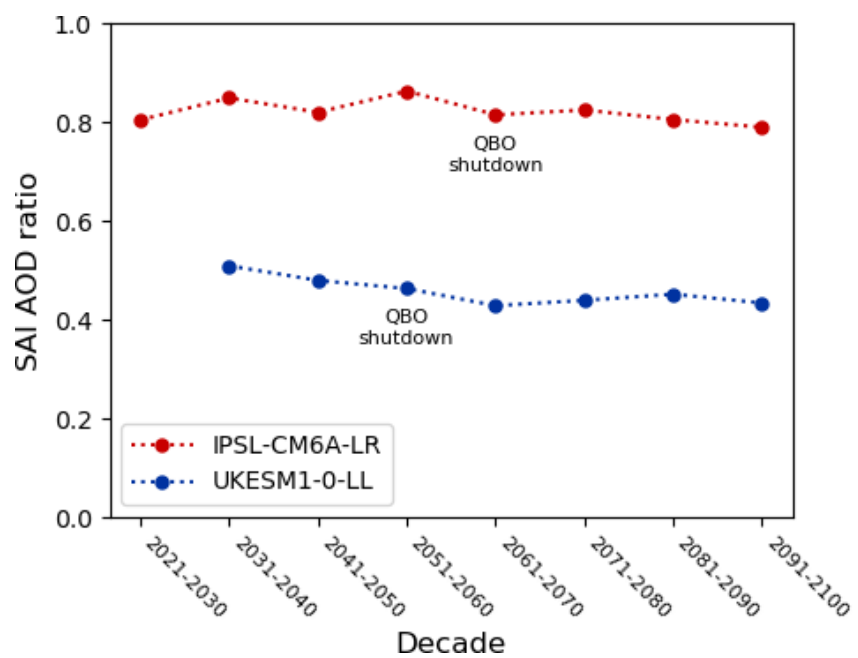

Figure 9. Evolution of the ratio of the mean stratospheric aerosol intervention (SAI) aerosol optical depth (AOD) in the subtropics to that in the $\mathrm{SO}_{2}$ injection zone in ensemble member $\mathrm{r} 1$ of the two models whose G6sulfur experiments have both interactive $\mathrm{SO}_{2}$ injection and a shutdown of the Quasi-Biennial Oscillation (QBO). The injection zone is the area between $10^{\circ} \mathrm{N}$ and $10^{\circ} \mathrm{S}$ as specified in Kravitz et al. (2015) and the subtropics are defined here as the region between $30^{\circ} \mathrm{N}$ and $30^{\circ} \mathrm{S}$ but excluding the injection zone. SAI was not required in UKESM1-0-LL until 2031 so the decade 2021-2030 is omitted for this model.

the $\mathrm{SO}_{2}$ and aerosol in the equatorial region during the westerly phase leads to increased aerosol growth and faster gravitational settling (Visioni et al., 2018). Obviously, the effect of a QBO shutdown in our simulations can only be examined in those models that both simulate $\mathrm{SAI}$ interactively by $\mathrm{SO}_{2}$ injection and have a QBO shutdown, namely IPSL-CM6ALR and UKESM1-0-LL. Figure 9 shows the evolution of the ratio of SAI AOD (inferred as the difference in stratospheric AOD between G6sulfur and ssp245) in the subtropics $\left(30^{\circ} \mathrm{N}-30^{\circ} \mathrm{S}\right.$ excluding $\left.10^{\circ} \mathrm{N}-10^{\circ} \mathrm{S}\right)$ to that in the SAI injection zone $\left(10^{\circ} \mathrm{N}-10^{\circ} \mathrm{S}\right)$. The value of this ratio clearly differs between the two models but it shows no significant change following QBO shutdown in either model, suggesting little impact on transport from the injection region.

\section{Discussion and Conclusions}

The results presented above support the conclusions of Jones et al. (2021) regarding the impact on the NAO in G6sulfur using a larger number of models. A robust agreement is found across the models that SAI in G6sulfur tends to induce a positive phase of the wintertime NAO leading to warmer and wetter winters over northern Eurasia with cooler and drier winters over southern Europe than in ssp245.

The spatial pattern of the multi-model mean precipitation changes over Europe in G6sulfur are very similar to observations of the impact of the positive phase of the NAO from the Global Precipitation Climatology Project (GPCP; Adler et al., 2003) as shown in Fig. 10, although obviously this is not an exact comparison as the NAO response in G6sulfur is diagnosed at the end of the 21st century. Observations show that during the positive phase of the NAO areas of Iberia and parts of southern Europe such as the Balkan peninsula and Anatolia show the most significant precipitation reductions, whereas western areas of Norway and the northwest of Scotland show the most significant precipitation increases (Fig. 10b), a pattern of changes that is largely reproduced in G6sulfur (Fig. 10c). This similarity between observations of the precipitation response to the positive phase of the NAO and the impact in G6sulfur gives additional confidence that the models are performing well. The issue of wintertime precipitation changes driven by changes in the phase of the NAO and the associated changes in the strength and position of the North Atlantic storm-track are unlikely to be solved by injecting $\mathrm{SO}_{2}$ using more sophisticated geographic injection strategies owing to the relatively long lifetime of the sulfuric acid aerosols in the stratosphere during which they may be transported (and induce stratospheric heating) far from the injection site. Simpson et al. (2019) and Banerjee et al. (2021) both performed simulations using the Geoengineering Large Ensemble (Tilmes et al., 2018b), where the injections were performed at latitudes of $30^{\circ} \mathrm{N}, 15^{\circ} \mathrm{N}$, $15^{\circ} \mathrm{S}$ and $30^{\circ} \mathrm{S}$, and both studies found a very similar forced positive phase of the DJF NAO to that found in G6sulfur using equatorial injection. Simpson et al. (2019) performed further experiments where the stratospheric heating was enhanced and found a stronger impact on the positive phase of the DJF NAO and the associated precipitation patterns, suggesting that the absorption of solar radiation at wavelengths greater than $\sim 1.3 \mu \mathrm{m}$ by stratospheric sulfuric acid aerosols (Dykema et al., 2016) is the root cause of this response. Consequently, any form of large-scale deployment of SAI using sulfuric acid aerosol is likely to affect the NAO in a manner similar to that described here. That only a small amount of aerosol absorption in the tail-end of the solar spectrum could have such impacts suggests that any proposals utilising even small amounts of highly absorbing aerosol such as black carbon (e.g. Gao et al., 2021) need to be treated with caution. As noted by Dykema et al. (2016), there are other candidate particles that absorb less solar radiation than sulfuric acid that might be considered more suitable, but climate modelling research into the impacts of such particles is still in its infancy. Additionally, the use of these alternative particles may be compromised by coatings of sulfuric acid from natural sources (McGrory et al., 2022).

In contrast to the results regarding the NAO, there is no consensus as to impacts on the QBO in G6sulfur. One model has the QBO locking into a persistent westerly phase within a few years of the commencement of SAI, in three models this effect does not occur until mid-century, and two models do not show this behaviour at all. The reasons for this are the subjects of future study, but the ability of models to ac- 

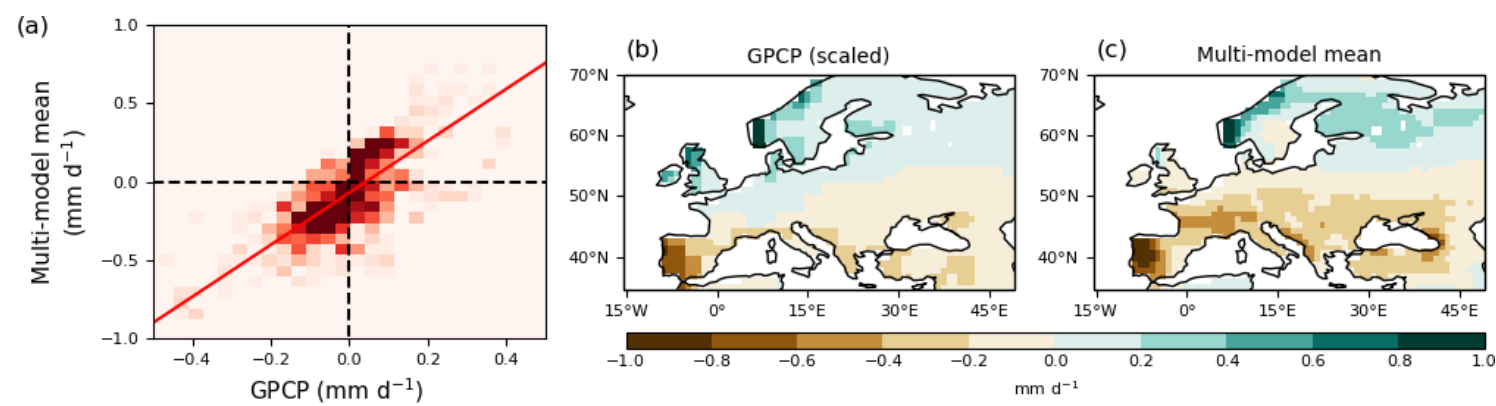

Figure 10. 2-D histogram and straight-line fit comparing the change in December to February (DJF) land precipitation rate over Europe $\left(\mathrm{mm} \mathrm{d}^{-1}\right)$ from Global Precipitation Climatology Project (GPCP) observations with the multi-model mean; the GPCP data are the differences between positive and negative North Atlantic Oscillation winters over 1979-2015 and the model data are the mean differences between G6sulfur and ssp245 for 2081-2100 (a). The difference in DJF land precipitation rate over Europe ( $\mathrm{mm} \mathrm{d}^{-1}$ ) from GPCP as defined in panel (a) scaled by the gradient (1.65) of the straight-line fit. The multi-model mean difference in DJF land precipitation rate over Europe $\left(\mathrm{mm} \mathrm{d}^{-1}\right)$ between G6sulfur and ssp245 for 2081-2100 (c).

curately simulate the unperturbed QBO is an obvious place to start. Nevertheless, despite the lack of consistency, the results indicate a clear risk that SAI by the equatorial injection of $\mathrm{SO}_{2}$ could cause a permanent shutdown of the QBO. We note that any impacts on the QBO may be reduced by injection strategies that do not inject $\mathrm{SO}_{2}$ directly at the Equator but are optimised to reduce residual climate impacts by injecting at $30^{\circ} \mathrm{N}$ and $30^{\circ} \mathrm{S}$ (Franke et al., 2021). Results from two of the models suggest that, even if the QBO does shut down, the impact on the distribution of stratospheric aerosols is likely to be small. However, a fixed westerly phase of the QBO could partly undermine the purpose of SAI by further exacerbating European temperature and rainfall changes via teleconnections with the NAO (Andrews et al., 2019) and it is recognised that further work in this area is needed.

Our strongest conclusion is that a forced positive phase of the DJF NAO and the associated shifts in precipitation over Europe are likely to remain systemic problems for any SAI strategy, particularly for Iberia, where the reduction in wintertime precipitation in G6sulfur is more significant than in the high-end climate change (ssp585) scenario that climate engineering was designed to mitigate. How such issues could be dealt with in terms of societal and economic remediation is beyond the scope of this work.

Code and data availability. All model data used in this work are available from the Earth System Grid Federation (WCRP, 2021; https://esgf-node.llnl.gov/projects/cmip6, last access: 14 July 2021).

Author contributions. AJ and JMH led the analysis and wrote the paper with contributions from all co-authors.
Competing interests. The contact author has declared that neither they nor their co-authors have any competing interests.

Disclaimer. Publisher's note: Copernicus Publications remains neutral with regard to jurisdictional claims in published maps and institutional affiliations.

Special issue statement. This article is part of the special issue "Resolving uncertainties in solar geoengineering through multimodel and large-ensemble simulations (ACP/ESD inter-journal SI)". It is not associated with a conference.

Acknowledgements. Andy Jones would like to thank the Met Office team responsible for the managecmip software, which greatly simplified data discovery and handling, and Neal Butchart for useful comments. Andy Jones, Jim M. Haywood and Adam A. Scaife were supported by the Met Office Hadley Centre Climate Programme funded by BEIS. Andy Jones and Jim M. Haywood would like to acknowledge funding provided by SilverLining through its Safe Climate Research Initiative. Jim M. Haywood and Matthew Henry were part-funded by the Natural Environment Research Council Exeter-NCAR (EXTEND) collaborative development grant (NE/W003880/1). The IPSL-CM6A-LR experiments were performed using the high-performance computing resources of TGCC under the allocations 2019-A0060107732 and 2020-A0080107732 (project gencmip6) provided by GENCI (Grand Equipement National de Calcul Intensif). IPSL benefited from French state aid managed by the ANR under the "Investissements d'avenir" programme with the reference ANR-11-IDEX0004-17-EURE-0006. Support for Ben Kravitz was provided in part by the National Science Foundation through agreement CBET1931641, the Indiana University Environmental Resilience Institute, and the Prepared for Environmental Change Grand Challenge initiative. The Pacific Northwest National Laboratory is operated for the US Department of Energy by Battelle Memorial Institute under contract DE-AC05-76RL01830. Roland Séférian and Pierre Nabat particularly acknowledge the support of the team in charge of 
the CNRM-CM climate model; supercomputing time was provided by the Météo-France/DSI supercomputing centre. Roland Séférian thanks Christophe Cassou for his fruitful discussion on the paper. CNRM-ESM2-1 simulations were supported by the European Union's Horizon 2020 research and innovation program via the H2020 projects CRESCENDO (grant agreement no. 641816) and CONSTRAIN (grant agreement no. 820829). Ulrike Niemeier was supported by the Deutsche Forschungsgemeinschaft Research Unit VollImpact (FOR2820 (grant no. 398006378)) and used resources of the Deutsches Klimarechenzentrum (DKRZ) granted by its Scientific Steering Committee (WLA) under project ID bm0550. We acknowledge the Copernicus Climate Change Service (C3S) Climate Data Store (CDS) for the ERA5 data.

Financial support. This research has been supported by the Department for Business, Energy and Industrial Strategy, UK Government; SilverLining, USA; the Natural Environment Research Council, UK (grant no. NE/W003880/1); the Agence Nationale de la Recherce, France (programme reference ANR-11-IDEX-000417-EURE-0006); the National Scicence Foundation, USA (agreement CBET-1931641); the Indiana University Environmental Resilience Institute, USA; the Prepared for Environmental Change Grand Challenge initiative, USA; the Horizon 2020 research and innovation program, European Union (grant agreement nos. 641816 and 820829); and the Deutsche Forschungsgemeinschaft Research Unit VollImpact, Germany (grant no. 398006378).

Review statement. This paper was edited by Farahnaz Khosrawi and reviewed by two anonymous referees.

\section{References}

Adler, R. F., Huffman, G. J., Chang, A., Ferraro, R., Xie, P.-P., Janowiak, J., Rudolf, B., Schneider, U., Curtis, S., Bolvin, D., Gruber, A., Susskind, J., Arkin, P., and Nelkin, E.: The Version-2 Global Precipitation Climatology Project (GPCP) monthly precipitation analysis (1979-present), J. Hydrometeorol., 4, 1147-1167, https://doi.org/10.1175/15257541(2003)004<1147:TVGPCP>2.0.CO;2, 2003.

Andrews, M. B., Knight, J. R., Scaife, A. A., Lu, Y., $\mathrm{Wu}$, T., Gray, L. J., and Schenzinger, V.: Observed and simulated teleconnections between the stratospheric QuasiBiennial Oscillation and Northern Hemisphere winter atmospheric circulation, J. Geophys. Res.-Atmos., 124, 1219-1232, https://doi.org/10.1029/2018JD029368, 2019.

Aquila, V., Garfinkel, C. I., Newman, P. A., Oman, L. D., and Waugh, D. W.: Modifications of the quasi-biennial oscillation by a geoengineering perturbation of the stratospheric aerosol layer, Geophys. Res. Lett., 41, 1738-1744, https://doi.org/10.1002/2013GL058818, 2014.

Baker, L. H., Shaffrey, L. C., Sutton, R. T., Weisheimer, A., and Scaife, A. A.: An intercomparison of skill and overconfidence/underconfidence of the wintertime North Atlantic Oscillation in multimodel seasonal forecasts, Geophys. Res. Lett., 45, 7808-7817, https://doi.org/10.1029/2018GL078838, 2018.
Baldwin, M. P., Gray, L. J., Dunkerton, T. J., Hamilton, K., Haynes, P. H., Randel, W. J., Holton, J. R., Alexander, M. J., Hirota, I., Horinouchi, T., Jones, D. B. A., Kinnersley, J. S., Marquardt, C., Sato, K., and Takahashi, M.: The quasi-biennial oscillation, Rev. Geophys., 39, 179-229, https://doi.org/10.1029/1999RG000073, 2001.

Banerjee, A., Butler, A. H., Polvani, L. M., Robock, A., Simpson, I. R., and Sun, L.: Robust winter warming over Eurasia under stratospheric sulfate geoengineering - the role of stratospheric dynamics, Atmos. Chem. Phys., 21, 6985-6997, https://doi.org/10.5194/acp-21-6985-2021, 2021.

Boucher, O., Denvil, S., Levavasseur, G., Cozic, A., Caubeel, A., Foujols, M.-A., Meurdesoif, Y., Cadule, P., Devilliers, M., Dupont, E., and Lurton, T.: IPSL IPSLCM6A-LR model output prepared for CMIP6 ScenarioMIP ssp245, Earth System Grid Federation [data set], https://doi.org/10.22033/ESGF/CMIP6.5264, 2019a.

Boucher, O., Denvil, S., Levavasseur, G., Cozic, A., Caubeel, A., Foujols, M.-A., Meurdesoif, Y., Cadule, P., Devilliers, M., Dupont, E., and Lurton, T.: IPSL IPSLCM6A-LR model output prepared for CMIP6 ScenarioMIP ssp585, Earth System Grid Federation [data set], https://doi.org/10.22033/ESGF/CMIP6.5271, 2019b.

Boucher, O., Denvil, S., Levavasseur, G., Cozic, A., Caubeel, A., Foujols, M.-A., Meurdesoif, Y., and Lurton, T.: IPSL IPSL-CM6A-LR model output prepared for CMIP6 GeoMIP G6solar, Earth System Grid Federation [data set], https://doi.org/10.22033/ESGF/CMIP6.5058, 2019c.

Boucher, O., Servonnat, J., Albright, A. L., Aumont, O., Balkanski, Y., Bastrikov, V., Bekki, S., Bonnet, R., Bony, S., Bopp, L., Braconnot, P., Brockmann, P., Cadule, P., Caubel, A., Cheruy, F., Codron, F., Cozic, A., Cugnet, D., D’Andrea, F., Davini, P., de Lavergne, C., Denvil, S., Deshayes, J., Devilliers, M., Ducharne, A., Dufresne, J.-L., Dupont, E., Éthé, C., Fairhead, L., Falletti, L., Flavoni, S., Foujols, M.-A., Gardoll, S., Gastineau, G., Ghattas, J., Grandpeix, J.-Y., Guenet, B., Guez, Lionel, E., Guilyardi, E., Guimberteau, M., Hauglustaine, D., Hourdin, F., Idelkadi, A., Joussaume, S., Kageyama, M., Khodri, M., Krinner, G., Lebas, N., Levavasseur, G., Lévy, C., Li, L., Lott, F., Lurton, T., Luyssaert, S., Madec, G., Madeleine, J.B., Maignan, F., Marchand, M., Marti, O., Mellul, L., Meurdesoif, Y., Mignot, J., Musat, I., Ottlé, C., Peylin, P., Planton, Y., Polcher, J., Rio, C., Rochetin, N., Rousset, C., Sepulchre, P., Sima, A., Swingedouw, D., Thiéblemont, R., Traore, A. K., Vancoppenolle, M., Vial, J., Vialard, J., Viovy, N., and Vuichard, N.: Presentation and evaluation of the IPSL-CM6A-LR climate model, J. Adv. Model. Earth Sy., 12, e2019MS002010, https://doi.org/10.1029/2019MS002010, 2020a.

Boucher, O., Denvil, S., Levavasseur, G., Cozic, A., Caubeel, A., Foujols, M.-A., Meurdesoif, Y., and Lurton, T.: IPSL IPSL-CM6A-LR model output prepared for CMIP6 GeoMIP G6sulfur, Earth System Grid Federation [data set], https://doi.org/10.22033/ESGF/CMIP6.5059, 2020b.

Casanueva, A., Rodríguez-Puebla, C., Frías, M. D., and GonzálezReviriego, N.: Variability of extreme precipitation over Europe and its relationships with teleconnection patterns, Hydrol. Earth Syst. Sci., 18, 709-725, https://doi.org/10.5194/hess-18709-2014, 2014. 
Christiansen, B.: Ensemble averaging and the curse of dimensionality, J. Climate, 31, 1587-1596, https://doi.org/10.1175/JCLID-17-0197.1, 2018.

Christidis, N., Jones, G. S., and Stott, P. A.: Dramatically increasing chance of extremely hot summers since the 2003 European heatwave, Nat. Clim. Change, 5, 46-50, https://doi.org/10.1038/NCLIMATE2468, 2015.

Danabasoglu, G.: NCAR CESM2-WACCM model output prepared for CMIP6 GeoMIP G6sulfur, Earth System Grid Federation [data set], https://doi.org/10.22033/ESGF/CMIP6.10034, 2019a.

Danabasoglu, G.: NCAR CESM2-WACCM model output prepared for CMIP6 ScenarioMIP ssp245, Earth System Grid Federation [data set], https://doi.org/10.22033/ESGF/CMIP6.10101, 2019b.

Danabasoglu, G.: NCAR CESM2-WACCM model output prepared for CMIP6 ScenarioMIP ssp585, Earth System Grid Federation [data set], https://doi.org/10.22033/ESGF/CMIP6.10115, 2019c.

Danabasoglu, G.: NCAR CESM2-WACCM model output prepared for CMIP6 GeoMIP G6solar, Earth System Grid Federation [data set], https://doi.org/10.22033/ESGF/CMIP6.10033, 2019d.

Danabasoglu, G., Lamarque, J.-F., Bacmeister, J., Bailey, D. A., DuVivier, A. K., Edwards, J., Emmons, L. K., Fasullo, J., Garcia, R., Gettelman, A., Hannay, C., Holland, M. M., Large, W. G., Lauritzen, P. H., Lawrence, D. M., Lenaerts, J. T. M., Lindsay, K., Lipscomb, W. H., Mills, M. J., Neale, R., Oleson, K. W., Otto-Bliesner, B., Phillips, A. S., Tilmes, S., van Kampenhout, L., Vertenstein, M., Bertini, A., Dennis, J, Deser, C., Fischer, C., Fox-Kemper, B., Kay, J. E., Kinnison, D., Kushner, P. J., Larson, V. E., Long, M. C., Mickelson, S., Moore, J. K., Nienhouse, E., Polvani, L., Rasch, P. J., and Strand, W. G.: The Community Earth System Model Version 2 (CESM2), J. Adv. Model. Earth Sy., 12, e2019MS001916, https://doi.org/10.1029/2019MS001916, 2020.

Driscoll, S., Bozzo, A., Gray, L. J., Robock, A., and Stenchikov, G.: Coupled Model Intercomparison Project 5 (CMIP5) simulations of climate following volcanic eruptions, J. Geophys. Res., 117, D17105, https://doi.org/10.1029/2012JD017607, 2012.

Dykema, J. D., Keith, D. W., and Keutsch, F. N.: Improved aerosol radiative properties as a foundation for solar geoengineering risk assessment, Geophys. Res. Lett., 43, 7758-7766, https://doi.org/10.1002/2016GL069258, 2016.

Eyring, V., Bony, S., Meehl, G. A., Senior, C. A., Stevens, B., Stouffer, R. J., and Taylor, K. E.: Overview of the Coupled Model Intercomparison Project Phase 6 (CMIP6) experimental design and organization, Geosci. Model Dev., 9, 1937-1958, https://doi.org/10.5194/gmd-9-1937-2016, 2016.

Fischer, E. M., Luterbacher, J., Zorita, E., Tett, S. F. B., Casty, C., and Wanner, H.: European climate response to tropical volcanic eruptions over the last half millennium, Geophys. Res. Lett., 34, L05707, https://doi.org/10.1029/2006GL027992, 2007.

Franke, H., Niemeier, U., and Visioni, D.: Differences in the quasi-biennial oscillation response to stratospheric aerosol modification depending on injection strategy and species, Atmos. Chem. Phys., 21, 8615-8635, https://doi.org/10.5194/acp-218615-2021, 2021.

Gao, R.-S., Rosenlof, K. H., Kärcher, B., Tilmes, S., Toon, O. B., Maloney, C., and Yu, P.: Toward practical stratospheric aerosol albedo modification: solar-powered lofting, Sci. Adv., 7, eabe3416, https://doi.org/10.1126/sciadv.abe3416, 2021.
Gettelman, A., Mills, M. J., Kinnison, D. E., Garcia, R. R., Smith, A. K., Marsh, D. R., Tilmes, S., Vitt, F., Bardeen, C. G., McInerny, J., Liu, H.-L., Solomon, S. C., Polvani, L. M., Emmons, L. K., Lamarque, J.-F., Richter, J. H., Glanville, A. S., Bacmeister, J. T., Phillips, A. S., Neale, R. B., Simpson, I. R., DuVivier, A. K., Hodzic, A., and Randel, W. J.: The Whole Atmosphere Community Climate Model Version 6 (WACCM6), J. Geophys. Res.-Atmos., 124, 12380-12403, https://doi.org/10.1029/2019JD030943, 2019.

Good, P., Sellar, A., Tang, Y., Rumbold, S., Ellis, R., Kelley, D., and Kuhlbrodt, T., MOHC UKESM1.0-LL model output prepared for CMIP6 ScenarioMIP ssp245, Earth System Grid Federation [data set], https://doi.org/10.22033/ESGF/CMIP6.6339, 2019a.

Good, P., Sellar, A., Tang, Y., Rumbold, S., Ellis, R., Kelley, D., and Kuhlbrodt, T., MOHC UKESM1.0-LL model output prepared for CMIP6 ScenarioMIP ssp585, Earth System Grid Federation [data set], https://doi.org/10.22033/ESGF/CMIP6.6405, 2019b.

Giorgetta, M. A., Manzini, E., and Roeckner, E.: Forcing of the quasi-biennial oscillation from a broad spectrum of atmospheric waves, Geophys. Res. Lett., 29, 1245, https://doi.org/10.102/2001GL014756, 2002.

Haywood, J. M., Jones, A., and Jones, G. S.: The impact of volcanic eruptions in the period 2000-2013 on global mean temperature trends evaluated in the HadGEM2-ES climate model, Atmos. Sci. Lett., 15, 92-96, https://doi.org/10.1002/asl2.471, 2014.

Hersbach, H., Bell, B., Berrisford, P., Biavati, G., Horányi, A., Muñoz Saabater, J., Nicolas, J., Peubey, C., Radu, R., Rozum, I., Schepers, D., Simmons, A., Soci, C., Dee, D., and Thépaut, J.N.: ERA5 monthly averaged data on pressure levels from 1979 to present, Copernicus Climate Change Service (C3S) Climate Data Store (CDS) [data set], https://doi.org/10.24381/cds.6860a573, 2019 (data available at: https://confluence.ecmwf.int/display/ CKB/How+to+download+ERA5, last access: 17 June 2021).

Holton, J. R.: Wave propagation and transportation in the middle atmosphere, Philos. T. Roy. Soc. A, 296, 73-85, https://doi.org/10.1098/rsta.1980.0157, 1980.

Hurrell, J. W.: Decadal trends in the North Atlantic Oscillation: regional temperatures and precipitation, Science, 269, 676-679, 70 https://doi.org/10.1126/science.269.5224.676, 1995.

Hurrell, J. and National Center for Atmospheric Research Staff (Eds): The Climate Data Guide: Hurrell North Atlantic Oscillation (NAO) Index (stationbased), https://climatedataguide.ucar.edu/climate-data/ hurrell-north-atlantic-oscillation-nao-index-station-based (access: 21 December 2021), 2020.

IPCC (Intergovernmental Panel on Climate Change): Global warming of $1.5^{\circ} \mathrm{C}$. An IPCC Special Report on the impacts of global warming of $1.5^{\circ} \mathrm{C}$ above pre-industrial levels and related global greenhouse gas emission pathways, in the context of strengthening the global response to the threat of climate change, sustainable development, and efforts to eradicate poverty, edited by: Masson-Delmotte, V., Zhai, P., Pörtner, H. O., Roberts, D., Skea, J., Shukla, P. R., Pirani, A., Moufouma-Okia, W., Péan, C., Pidcock, R., Connors, S., Matthews, J. B. R., Chen, Y., Zhou, X., Gomis, M. I., Lonnoy, E., Maycock, T., Tignor, M., and Waterfield, T., https://www.ipcc.ch/sr15/ (last access: 12 August 2021), 2018. 
Jones, A.: MOHC UKESM1.0-LL model output prepared for CMIP6 GeoMIP G6sulfur, Earth System Grid Federation [data set], https://doi.org/10.22033/ESGF/CMIP6.5822, 2019a.

Jones, A.: MOHC UKESM1.0-LL model output prepared for CMIP6 GeoMIP G6solar, Earth System Grid Federation [data set], https://doi.org/10.22033/ESGF/CMIP6.5820, 2019b.

Jones, A., Haywood, J. M., Jones, A. C., Tilmes, S., Kravitz, B., and Robock, A.: North Atlantic Oscillation response in GeoMIP experiments G6solar and G6sulfur: why detailed modelling is needed for understanding regional implications of solar radiation management, Atmos. Chem. Phys., 21, 1287-1304, https://doi.org/10.5194/acp-21-1287-2021, 2021.

Jones, A. C., Haywood, J. M., and Jones, A.: Climatic impacts of stratospheric geoengineering with sulfate, black carbon and titania injection, Atmos. Chem. Phys., 16, 2843-2862, https://doi.org/10.5194/acp-16-2843-2016, 2016.

Jones, A. C., Hawcroft, M. K., Haywood, J. M., Jones, A., Guo, X., and Moore, J. C.: Regional climate impacts of stabilizing global warming at $1.5 \mathrm{~K}$ using solar geoengineering, Earth's Future, 6, 230-251, https://doi.org/10.1002/2017EF000720, 2018.

Kidston, J., Scaife, A. A., Hardiman, S. C., Mitchell, D. M., Butchart, N., Baldwin, M. P., and Gray, L. J.: Stratospheric influence on tropospheric jet streams, storm tracks and surface weather, Nat. Geosci., 8, 433-440, https://doi.org/10.1038/ngeo2424, 2015.

Knutson, T., Camargo, S. J., Chan, J. C. L., Emanuel, K., Ho, C.-H., Kossin, J., Mohapatra, M., Satoh, M., Sugi, M., Walsh, K., and Wu, L.: Tropical cyclones and climate change assessment: Part II: Projected response to anthropogenic warming, B. Am. Meteorol. Soc., 101, E303-E322, https://doi.org/10.1175/BAMS-D18-0194.1, 2020.

Kravitz, B., Robock, A., Boucher, O., Schmidt, H., Taylor, K. E., Stenchikov, G., and Schulz, M.: The geoengineering model intercomparison project (GeoMIP), Atmos. Sci. Lett., 12, 162-167, https://doi.org/10.1002/as1.316, 2011.

Kravitz, B., Caldeira, K., Boucher, O., Robock, A., Rasch, P. J., Alterskjær, K., Bou Karam, D., Cole, J. N. S., Curry, C. L., Haywood, J. M., Irvine, P. J., Ji, D., Jones, A., Kristjánsson, J. E., Lunt, D. J., Moore, J. C., Niemeier, U., Schmidt, H., Schulz, M., Singh, B., Tilmes, S., Watanabe, S., Yang, S., and Yoon, J.-H.: Climate model response from the geoengineering model intercomparison project (GeoMIP), J. Geophys. Res.-Atmos., 118, 8320-8332, https://doi.org/10.1002/jgrd.50646, 2013.

Kravitz, B., Robock, A., Tilmes, S., Boucher, O., English, J. M., Irvine, P. J., Jones, A., Lawrence, M. G., MacCracken, M., Muri, H., Moore, J. C., Niemeier, U., Phipps, S. J., Sillmann, J., Storelvmo, T., Wang, H., and Watanabe, S.: The Geoengineering Model Intercomparison Project Phase 6 (GeoMIP6): simulation design and preliminary results, Geosci. Model Dev., 8, 3379_ 3392, https://doi.org/10.5194/gmd-8-3379-2015, 2015.

Kravitz, B., MacMartin, D. G., Visioni, D., Boucher, O., Cole, J. N. S., Haywood, J., Jones, A., Lurton, T., Nabat, P., Niemeier, U., Robock, A., Séférian, R., and Tilmes, S.: Comparing different generations of idealized solar geoengineering simulations in the Geoengineering Model Intercomparison Project (GeoMIP), Atmos. Chem. Phys., 21, 4231-4247, https://doi.org/10.5194/acp21-4231-2021, 2021

Lawrence, M. G., Schäfer, S., Muri, H., Scott, V., Oschlies, A., Vaughan, N. E., Boucher, O., Schmidt, H., Haywood, J., and
Scheffran, J.: Evaluating climate geoengineering proposals in the context of the Paris Agreement temperature goals, Nat. Commun., 9, 3734, https://doi.org/10.1038/s41467-018-059383, 2018.

Lenton, T. M., Rockström, J., Gaffney, O., Rahmstorf, S., Richardson, K., Steffen, W., and Schellnhuber, H. J.: Climate tipping points - too risky to bet against, Nature, 575, 592-595, https://doi.org/10.1038/d41586-019-03595-0, 2019.

Lindzen, R. S. and Holton, J. R.: A theory of the quasi-biennial oscillation, J. Atmos. Sci. 25, 1095-1107, https://doi.org/10.1175/15200469(1968)025<1095:ATOTQB>2.0.CO;2, 1968.

López-Moreno, J. I. and Vicente-Serrano, S. M.: Positive and negative phases of the wintertime North Atlantic Oscillation and drought occurrence over Europe: a multitemporal-scale approach, J. Climate, 21, 1220-1243, https://doi.org/10.1175/2007JCLI1739.1, 2008.

Lurton, T., Balkanski, Y., Bastrikov, V., Bekki, S., Bopp, L., Braconnot, P., Brockmann, P., Cadule, P., Contoux, C., Cozic, A., Cugnet, D., Dufresne, J.-L., Éthé, C., Foujols, M.-A., Ghattas, J., Hauglustaine, D., Hu, R.-M., Kageyama, M., Khodri, M., Lebas, N., Levavasseur, G., Marchand, M., Ottlé, C., Peylin, P., Sima, A., Szopa, S., Thiéblemont, R., Vuichard, N., and Boucher, O.: Implementation of the CMIP6 forcing data in the IPSL-CM6ALR model, J. Adv. Model. Earth Sy., 12, e2019MS001940, https://doi.org/10.1029/2019MS001940, 2020.

MacMartin, D. G., Ricke, K. L., and Keith, D. W.: Solar geoengineering as part of an overall strategy for meeting the $1.5^{\circ} \mathrm{C}$ Paris target, Philos. T. Roy. Soc. A, 376, 20160454, https://doi.org/10.1098/rsta.2016.0454, 2018.

Marshall, A. G., Scaife, A. A., and Ineson, S.: Enhanced seasonal prediction of European winter warming following volcanic eruptions, J. Climate, 22, 6168-6180, https://doi.org/10.1175/2009JCLI3145.1, 2009.

McGrory, M. R., Shepherd, R. H., King, M. D., Davidson, N., Pope, F. D., Watson, I. M., Grainger, R. G., Jones, A. C., and Ward, A. D.: Mie scattering from optically levitated mixed sulfuric acid-silica core-shell aerosols: observation of core-shell morphology for atmospheric science, Phys. Chem. Chem. Phys., https://doi.org/10.1039/D1CP04068E, 2022.

Millar, R. J., Fuglestvedt, J. S., Friedlingstein, P., Rogelj, J., Grubb, M. J., Matthews, H. D., Skeie, R. B., Forster, P. M., Frame, D. J., and Allen, M. R.: Emission budgets and pathways consistent with limiting warming to $1.5^{\circ} \mathrm{C}$, Nat. Geosci., $10,741-747$, https://doi.org/10.1038/ngeo3031, 2017.

Molina, M. O., Sánchez, E., and Gutiérrez, C.: Future heat waves over the Mediterranean from an Euro-CORDEX regional climate model ensemble, Nature Sci. Rep., 10, 8801, https://doi.org/10.1038/s41598-020-65663-0, 2020.

Müller, W. A., Jungclaus, J. H., Mauritsen, T., Baehr, J., Bittner, M., Budich, R., Bunzel, F., Esch, M., Ghosh, R., Haak, H., Ilyina, T., Kleine, T., Kornblueh, L., Li, H., Modali, K., Notz, D., Pohlmann, H., Roeckner, E., Stemmler, I., Tian, F., and Marotzke, J.: A higher-resolution version of the Max Planck Institute Earth System Model (MPI85 ESM1.2-HR), J. Adv. Model. Earth Sy., 10, 1383-1413, https://doi.org/10.1029/2017MS001217, 2018.

Myhre, G., Alterskjær, K., Stjern, C. W., Hodnebrog, Ø., Marelle, L., Samset, B. H., Sillmann, J., Schaller, N., Fischer, E., Schulz, 
M., and Stohl, A.: Frequency of extreme precipitation increases extensively with event rareness under global warming, Nature Sci. Rep., 9, 16063, https://doi.org/10.1038/s41598-019-522774, 2019.

NAS (National Academies of Sciences, Engineering, and Medicine): Reflecting Sunlight: Recommendations for Solar Geoengineering Research and Research Governance, The National Academies Press, Washington, DC, USA, https://doi.org/10.17226/25762, 2021.

Niemeier, U., Schmidt, H., and Timmreck, C.: The dependency of geoengineered sulfate aerosol on the emission strategy, Atmos. Sci. Lett., 12, 189-194, https://doi.org/10.1002/asl.304, 2011.

Niemeier, U. and Schmidt, H.: Changing transport processes in the stratosphere by radiative heating of sulfate aerosols, Atmos. Chem. Phys., 17, 14871-14886, https://doi.org/10.5194/acp-1714871-2017, 2017.

Niemeier, U., Wieners, K.-H., Giorgetta, M., Jungclaus, J., Reick, C., Esch, M., Bittner, M., Legutke, S., Schupfner, M., Wachsmann, F., Gayler, V., Haak, H., de Vrese, P., Raddatz, T., Mauritsen, T., von Storch, J.-S., Behrens, J., Brovkin, V., Claussen, M., Crueger, T., Fast, I., Fiedler, S., Hagemann, S., Hohenegger, C., Jahns, T., Kloster, S., Kinne, S., Lasslop, G., Kornblueh, L., Marotzke, J., Matei, D., Meraner, K., Mikolajewicz, U., Modali, K., Müller,W., Nabel, J.,Notz, D., Peters-von Gehlen, K., Pincus, R., Pohlmann, H., Pongratz, J., Rast, S., Schmidt, H., Schnur, R., Schulzweida, U., Six, K., Stevens, B., Voigt, A., and Roeckner, E.: MPI-M MPI-ESM1.2-LR model output prepared for CMIP6 GeoMIP G6sulfur, Earth System Grid Federation [data set], https://doi.org/10.22033/ESGF/CMIP6.6448, 2019a.

Niemeier, U., Wieners, K.-H., Giorgetta, M., Jungclaus, J., Reick, C., Esch, M., Bittner, M., Legutke, S., Schupfner, M., Wachsmann, F., Gayler, V., Haak, H., de Vrese, P., Raddatz, T., Mauritsen, T., von Storch, J.-S., Behrens, J., Brovkin, V., Claussen, M., Crueger, T., Fast, I., Fiedler, S., Hagemann, S., Hohenegger, C., Jahns, T., Kloster, S., Kinne, S., Lasslop, G., Kornblueh, L., Marotzke, J., Matei, D., Meraner, K., Mikolajewicz, U., Modali, K., Müller, W., Nabel, J., Notz, D., Peters-von Gehlen, K., Pincus, R., Pohlmann, H., Pongratz, J., Rast, S., Schmidt, H., Schnur, R., Schulzweida, U., Six, K., Stevens, B., Voigt, A., and Roeckner, E.: MPI-M MPI-ESM1.2-LR model output prepared for CMIP6 GeoMIP G6solar, Earth System Grid Federation [data set], https://doi.org/10.22033/ESGF/CMIP6.6447, 2019b.

Niemeier, U., Wieners, K.-H., Giorgetta, M., Jungclaus, J., Reick, C., Esch, M., Bittner, M., Legutke, S., Schupfner, M., Wachsmann, F., Gayler, V., Haak, H., de Vrese, P., Raddatz, T., Mauritsen, T., von Storch, J.-S., Behrens, J., Brovkin, V., Claussen, M., Crueger, T., Fast, I., Fiedler, S., Hagemann, S., Hohenegger, C., Jahns, T., Kloster, S., Kinne, S., Lasslop, G., Kornblueh, L., Marotzke, J., Matei, D., Meraner, K., Mikolajewicz, U., Modali, K., Müller, W., Nabel, J., Notz, D., Peters-von Gehlen, K., Pincus, R., Pohlmann, H., Pongratz, J., Rast, S., Schmidt, H., Schnur, R., Schulzweida, U., Six, K., Stevens, B., Voigt, A., and Roeckner, E.: MPI-M MPI-ESM1.2-HR model output prepared for CMIP6 GeoMIP G6sulfur, Earth System Grid Federation [data set], https://doi.org/10.22033/ESGF/CMIP6.15300, 2019c.

Niemeier, U., Wieners, K.-H., Giorgetta, M., Jungclaus, J., Reick, C., Esch, M., Bittner, M., Legutke, S., Schupfner, M., Wachsmann, F., Gayler, V., Haak, H., de Vrese, P., Raddatz, T., Mau- ritsen, T., von Storch, J.-S., Behrens, J., Brovkin, V., Claussen, M., Crueger, T., Fast, I., Fiedler, S., Hagemann, S., Hohenegger, C., Jahns, T., Kloster, S., Kinne, S., Lasslop, G., Kornblueh, L., Marotzke, J., Matei, D., Meraner, K., Mikolajewicz, U., Modali, K., Müller, W., Nabel, J., Notz, D., Peters-von Gehlen, K., Pincus, R., Pohlmann, H., Pongratz, J., Rast, S., Schmidt, H., Schnur, R., Schulzweida, U., Six, K., Stevens, B., Voigt, A., and Roeckner, E.: MPI-M MPI-ESM1.2-HR model output prepared for CMIP6 GeoMIP G6solar, Earth System Grid Federation [data set], https://doi.org/10.22033/ESGF/CMIP6.15299, 2019d.

Niemeier, U., Richter, J. H., and Tilmes, S.: Differing responses of the quasi-biennial oscillation to artificial $\mathrm{SO}_{2}$ injections in two global models, Atmos. Chem. Phys., 20, 8975-8987, https://doi.org/10.5194/acp-20-8975-2020, 2020.

O’Neill, B. C., Tebaldi, C., van Vuuren, D. P., Eyring, V., Friedlingstein, P., Hurtt, G., Knutti, R., Kriegler, E., Lamarque, J.-F., Lowe, J., Meehl, G. A., Moss, R., Riahi, K., and Sanderson, B. M.: The Scenario Model Intercomparison Project (ScenarioMIP) for CMIP6, Geosci. Model Dev., 9, 3461-3482, https://doi.org/10.5194/gmd-9-3461-2016, 2016.

Osprey, S. M., Butchart, N., Knight, J. R., Scaife, A. A., Hamilton, K., Anstey, J. A., Schenzinger, V., and Zhang, C.: An unexpected disruption of the atmospheric quasi-biennial oscillation, Science, 353, 1424-1427, https://doi.org/10.1126/science.aah4156, 2016.

Perkins-Kirkpatrick, S. E. and Lewis, S. C.: Increasing trends in regional heatwaves, Nat. Commun., 11, 3357, https://doi.org/10.1038/s41467-020-16970-7, 2020.

Polvani, L. M., Banerjee, A., and Schmidt, A.: Northern Hemisphere continental winter warming following the $1991 \mathrm{Mt}$ Pinatubo eruption: reconciling models and observations, Atmos. Chem. Phys., 19, 6351-6366, https://doi.org/10.5194/acp19-6351-2019, 2019.

Punge, H. J., Konopka, P., Giorgetta, M. A., and Müller, R.: Effects of the quasi-biennial oscillation on lowlatitude transport in the stratosphere derived from trajectory calculations, J. Geophys. Res.-Atmos., 114, D03102, https://doi.org/10.1029/2008JD010518, 2009.

Richter, J. H., Tilmes, S., Mills, M. J., Tribbia, J. J., Kravitz, B., MacMartin, D. G., Vitt, F., and Lamarque, J.-F.: Stratospheric dynamical response and ozone feedbacks in the presence of $\mathrm{SO}_{2}$ injections, J. Geophys. Res.-Atmos., 122, 12557-12573, https://doi.org/10.1002/2017JD026912, 2017.

Richter, J. H., Anstey, J. A., Butchart, N., Kawatani, Y., Meehl, G. A., Osprey, S., and Simpson, I. R.: Progress in simulating the quasi-biennial oscillation in CMIP models, J. Geophys. Res.-Atmos., 125, e2019JD032362, https://doi.org/10.1029/2019JD032362, 2020.

Robock, A. and Mao, J.: Winter warming from large volcanic eruptions, Geophys. Res. Lett., 19, 2405-2408, https://doi.org/10.1029/92GL02627, 1992.

Rodwell, M. J., Rowell, D. P., and Folland, C. K.: Oceanic forcing of the wintertime North Atlantic Oscillation and European climate, Nature, 398, 320-323, https://doi.org/10.1038/18648, 1999.

Rogelj, J., den Elzen, M., Höhne, N., Fransen, T., Fekete, H., Winkler, H., Schaeffer, R., Sha, F., Riahi, K., and Meinshausen, M.: Paris Agreement climate proposals need a boost to keep warming well below $2{ }^{\circ} \mathrm{C}$, Nature, 534, 631-639, https://doi.org/10.1038/nature18307, 2016. 
Royal Society: Geoengineering the Climate: Science, Governance and Uncertainty, RS Policy Document 10/09 RS1636, The Royal Society, London, UK, https://eprints.soton.ac.uk/ 156647/1/Geoengineering_the_climate.pdf (last access: $12 \mathrm{Au}-$ gust 2021), 2009.

Samaniego, L., Thober, S., Kumar, R., Wanders, N., Rakovec, O., Pan, M., Zink, M., Sheffield, J., Wood, E. F., and Marx, A., Anthropogenic warming exacerbates European soil moisture droughts, Nat. Clim. Change, 8, 421-426, https://doi.org/10.1038/s41558-018-0138-5, 2018.

Santer, B. D., Bonfils, C., Painter, J. F., Zelinka, M. D., Mears, C., Solomon, S., Schmidt, G. A., Fyfe, J. C., Cole, J. N. S., Nazarenko, L.and Taylor,K. E.:Volcanic contribution todecadal changes in tropospheric temperature, Nat. Geosci., 7, 185-189, https://doi.org/10.1038/ngeo2098, 2014.

Scaife, A. A., Butchart, N., Warner, C. D., Stainforth, D., Norton, W., and Austin J.: Realistic quasi-biennial oscillations in a simulation of the global climate, Geophys. Res. Lett., 27, 3481-3484, https://doi.org/10.1029/2000GL011625, 2000.

Scaife, A. A., Knight, J. R., Vallis, G. K., and Folland, C. K.: A stratospheric influence on the winter NAO and North Atlantic surface climate, Geophys. Res. Lett., 32, L18715, https://doi.org/10.1029/2005GL023226, 2005.

Scaife, A. A., Folland, C. K., Alexander, L. V., Moberg, A., and Knight, J. R.: European climate extremes and the North Atlantic Oscillation, J. Climate, 21, 72-83, https://doi.org/10.1175/2007JCLI1631.1, 2008.

Schmidt, A., Mills, M. J., Ghan, S., Gregory, J. M., Allan, R. P., Andrews, T., Bardeen, C. G., Conley, A., Forster, P. M., Gettelman, A., Portmann, R. W., Solomon, S., and Toon, O. B., Volcanic radiative forcing from 1979 to 2015, J. Geophys. Res.-Atmos., 123, 12,491-12,508, https://doi.org/10.1029/2018JD028776, 2018.

Schupfner, M., Wieners, K.-H., Wachsmann, F., Steger, C., Bittner, M., Jungclaus, J., Früh, B., Pankatz, K., Giorgetta, M., Reick, C., Legutke, S., Esch, M., Gayler, V., Haak, H., de Vrese, P., Raddatz, T., Mauritsen, T., von Storch, J.-S., Behrens, J., Brovkin, V., Claussen, M., Crueger, T., Fast, I., Fiedler, S., Hagemann, S., Hohenegger, C., Jahns, T., Kloster, S., Kinne, S., Lasslop, G., Kornblueh, L., Marotzke, J., Matei, D., Meraner, K., Mikolajewicz, U., Modali, K., Müller, W., Nabel, J., Notz, D., Peters-von Gehlen, K., Pincus, R., Pohlmann, H., Pongratz, J., Rast, S., Schmidt, H., Schnur, R., Schulzweida, U., Six, K., Stevens, B., Voigt, A., and Roeckner, E.: DKRZ MPI-ESM1.2-HR model output prepared for CMIP6 ScenarioMIP ssp245, Earth System Grid Federation [data set], https://doi.org/10.22033/ESGF/CMIP6.4398, 2019a.

Schupfner, M., Wieners, K.-H., Wachsmann, F., Steger, C., Bittner, M., Jungclaus, J., Früh, B., Pankatz, K., Giorgetta, M., Reick, C., Legutke, S., Esch, M., Gayler, V., Haak, H., de Vrese, P., Raddatz, T., Mauritsen, T., von Storch, J.-S., Behrens, J., Brovkin, V., Claussen, M., Crueger, T., Fast, I., Fiedler, S., Hagemann, S., Hohenegger, C., Jahns, T., Kloster, S., Kinne, S., Lasslop, G., Kornblueh, L., Marotzke, J., Matei, D., Meraner, K., Mikolajewicz, U., Modali, K., Müller, W., Nabel, J., Notz, D., Peters-von Gehlen, K., Pincus, R., Pohlmann, H., Pongratz, J., Rast, S., Schmidt, H., Schnur, R., Schulzweida, U., Six, K., Stevens, B., Voigt, A., and Roeckner, E.: DKRZ MPI-ESM1.2-HR model output prepared for CMIP6 Sce-
narioMIP ssp585, Earth System Grid Federation [data set], https://doi.org/10.22033/ESGF/CMIP6.4403, 2019b.

Séférian, R.: CNRM-CERFACS CNRM-ESM2-1 model output prepared for CMIP6 GeoMIP G6sulfur, Earth System Grid Federation [data set], https://doi.org/10.22033/ESGF/CMIP6.3907, 2019.

Séférian, R.: CNRM-CERFACS CNRM-ESM2-1 model output prepared for CMIP6 GeoMIP G6solar, Earth System Grid Federation [data set], https://doi.org/10.22033/ESGF/CMIP6.3906, 2020.

Séférian, R., Nabat, P., Michou, M., Saint-Martin, D., Voldoire, A., Colin, J., Decharme, B., Delire, C., Berthet, S., Chevallier, M., Sénési, S., Franchisteguy, L., Vial, J., Mallet, M., Joetzjer, E., Geoffroy, O., Guérémy, J.-F., Moine, M.-P., Msadek, R., Ribes, A., Rocher, M., Roehrig, R., Salas-y-Mélia, D., Sanchez, E., Terray, L., Valcke, S., Waldman, R., Aumont, O., Bopp, L., Deshayes, J., Éthé, C., and Madec, G.: Evaluation of CNRM Earth System Model, CNRM-ESM2-1: Role of Earth system processes in present-day and future climate, J. Adv. Model. Earth Sy., 11, 4182-4227, https://doi.org/10.1029/2019MS001791, 2019.

Sellar, A., Jones, C. G., Mulcahy, J. P., Tang, Y., Yool, A., Wiltshire, A., O'Connor, F. M., Stringer, M., Hill, R., Palmieri, J., Woodward, S., de Mora, L., Kuhlbrodt, T., Rumbold, S., Kelley, D. I., Ellis, R., Johnson, C. E., Walton, J., Abraham, N. L., Andrews, M. B., Andrews, T., Archibald, A. T., Berthou, S., Burke, E., Blockley, E., Carslaw, K., Dalvi, M., Edwards, J., Folberth, G. A., Gedney, N., Griffiths, P. T., Harper, A. B., Hendry, M. A., Hewitt, A. J., Johnson, B., Jones, A., Jones, C. D., Keeble, J., Liddicoat, S., Morgenstern, O., Parker, R. J., Predoi, V., Robertson, E., Siahaan, A., Smith, R. S., Swaminathan, R., Woodhouse, M., Zeng, G., and Zerroukat, M.: UKESM1: Description and evaluation of the UK Earth System Model, J. Adv. Model. Earth Sy., 11, 4513-4558, https://doi.org/10.1029/2019MS001739, 2019.

Shindell, D. T., Schmidt, G. A., Mann, M. E., and Faluvegi, G.: Dynamic winter climate response to large tropical volcanic eruptions since 1600, J. Geophys. Res., 109, D05104, https://doi.org/10.1029/2003JD004151, 2004.

Simpson, I. R., Tilmes, S., Richter, J. H., Kravitz, B., MacMartin, D. G., Mills, M. J., Fasullo, J. T., and Pendergrass, A. G.: The regional hydroclimate response to stratospheric sulfate geoengineering and the role of stratospheric heating, J. Geophys. Res.-Atmos, 124, 12587-12616, https://doi.org/10.1029/2019JD031093, 2019.

Soden, B. J., Wetherald, R. T., Stenchikov, G. L., and Robock, A.: Global cooling after the eruption of Mount Pinatubo: A test of climate feedback by water vapor, Science, 296, 727-730, https://doi.org/10.1126/science.296.5568.727, 2002.

Stenchikov, G., Robock, A., Ramaswamy, V., Schwarzkopf, M. D., Hamilton, K., and Ramachandran S.: Arctic Oscillation response to the 1991 Mount Pinatubo eruption: Effects of volcanic aerosols and ozone depletion, J. Geophys. Res., 107, 4803, https://doi.org/10.1029/2002JD002090, 2002.

Stephenson, D. B., Pavan, V., Collins, M., Junge, M. M., Quadrelli, R., and Participating CMIP2 Modelling Groups: North Atlantic Oscillation response to transient greenhouse gas forcing and the impact on European winter climate: A CMIP2 multi-model assessment, Clim. Dynam., 27, 401-420, https://doi.org/10.1007/s00382-006-0140-x, 2006. 
Tebaldi, C. and Knutti, R.: The use of the multi-model ensemble 90 in probabilistic climate projections, Philos. T. Roy. Soc. A, 365, 2053-2075, https://doi.org/10.1098/rsta.2007.2076, 2007.

Tilmes, S., Fasullo, J., Lamarque, J.-F., Marsh, D. R., Mills, M., Alterskjær, K., Muri, H., Kristjánsson, J. E., Boucher, O., Schulz, M., Cole, J. N. S., Curry, C. L., Jones, A., Haywood, J., Irvine, P. J., Ji, D., Moore, J. C., Bou Karam, D., Kravitz, B., Rasch, P. J., Singh, B., Yoon, J.-H., Niemeier, U., Schmidt, H., Robock, A., Yang, S., and Watanabe, S.: The hydrological impact of geoengineering in the Geoengineering Model Intercomparison Project (GeoMIP), J. Geophys. Res.-Atmos., 118, 11036-11058, https://doi.org/10.1002/jgrd.50868, 2013.

Tilmes, S., Mills, M. J., Niemeier, U., Schmidt, H., Robock, A., Kravitz, B., Lamarque, J.-F., Pitari, G., and English, J. M.: A new Geoengineering Model Intercomparison Project (GeoMIP) experiment designed for climate and chemistry models, Geosci. Model Dev., 8, 43-49, https://doi.org/10.5194/gmd-8-43-2015, 2015.

Tilmes, S., Sanderson, B. M., and O'Neill, B. C.: Climate impacts of geoengineering in a delayed mitigation scenario, Geophys. Res. Lett., 43, 8222-8229, https://doi.org/10.1002/2016GL070122, 2016.

Tilmes, S., Richter, J. H., Mills, M. J., Kravitz, B., MacMartin, D. G., Garcia, R. R., Kinnison, D. E., Lamarque, J.-F., Tribbia, J., and Vitt, F.: Effects of different stratospheric $\mathrm{SO}_{2}$ injection altitudes on stratospheric chemistry and dynamics, J. Geophys. Res.-Atmos., 123, 4654-4673, https://doi.org/10.1002/2017JD028146, 2018a.

Tilmes, S., Richter, J. H., Kravitz, B., MacMartin, D. G., Mills, M. J., Simpson, I. R., Glanville, A. S., Fasullo, J. T., Phillips, A. S., Lamarque, J.-F., Tribbia, J., Edwards, J., Mickelson, S., and Ghosh, S.: CESM1(WACCM) stratospheric aerosol geoengineering large ensemble project, B. Am. Meteorol. Soc., 99, 23612371, https://doi.org/10.1175/BAMS-D-17-0267.1, 2018b.

Tollefson, J.: IPCC says limiting global warming to $1.5^{\circ} \mathrm{C}$ will require drastic action, Nature, 562, 172-173, https://doi.org/10.1038/d41586-018-06876-2, 2018.

Trigo, R. M., Pozo-Vázquez, D., Osborn, T. J., Castro-Díez, Y., Gámiz-Fortis, S., and Esteban-Parra, M. J.: North Atlantic Oscillation influence on precipitation, river flow and water resources in the Iberian Peninsula, Int. J. Climatol., 24, 925-944, https://doi.org/10.1002/joc.1048, 2004.

Tsanis, I. and Tapoglou, E.: Winter North Atlantic Oscillation impact on European precipitation and drought under climate change, Theor. App. Climatol., 135, 323-330, https://doi.org/10.1007/s00704-018-2379-7, 2019.

Visioni, D., Pitari, G., Tuccella, P., and Curci, G.: Sulfur deposition changes under sulfate geoengineering conditions: quasibiennial oscillation effects on the transport and lifetime of stratospheric aerosols, Atmos. Chem. Phys., 18, 2787-2808, https://doi.org/10.5194/acp-18-2787-2018, 2018.

Visioni, D., MacMartin, D. G., Kravitz, B., Boucher, O., Jones, A., Lurton, T., Martine, M., Mills, M. J., Nabat, P., Niemeier, U., Séférian, R., and Tilmes, S.: Identifying the sources of uncertainty in climate model simulations of solar radiation modification with the G6sulfur and G6solar Geoengineering Model Intercomparison Project (GeoMIP) simulations, Atmos. Chem. Phys., 21, 10039-10063, https://doi.org/10.5194/acp-21-100392021, 2021.
Voldoire, A.: CNRM-CERFACS CNRM-ESM2-1 model output prepared for CMIP6 ScenarioMIP ssp245, Earth System Grid Federation [data set], https://doi.org/10.22033/ESGF/CMIP6.4191, 2019a.

Voldoire, A.: CNRM-CERFACS CNRM-ESM2-1 model output prepared for CMIP6 ScenarioMIP ssp585, Earth System Grid Federation [data set], https://doi.org/10.22033/ESGF/CMIP6.4226, 2019b.

Wang, J., Kim, H.-M., and Chang, E. K. M.: Interannual modulation of Northern Hemisphere winter storm tracks by the QBO, Geophys. Res. Lett., 45, 2786-2794, https://doi.org/10.1002/2017GL076929, 2018.

WCRP (World Climate Research Programme): CMIP6 project data, ESGF [data set], https://esgf-node.llnl.gov/projects/cmip6/, last access: 14 July 2021.

Wieners, K.-H., Giorgetta, M., Jungclaus, J., Reick, C., Esch, M., Bittner, M., Gayler, V., Haak, H., de Vrese, P., Raddatz, T., Mauritsen, T., von Storch, J.-S., Behrens, J., Brovkin, V., Claussen, M., Crueger, T., Fast, I., Fiedler, S., Hagemann, S., Hohenegger, C., Jahns, T., Kloster, S., Kinne, S., Lasslop, G., Kornblueh, L., Marotzke, J., Matei, D., Meraner, K., Mikolajewicz, U., Modali, K., Müller, W., Nabel, J., Notz, D., Peters-von Gehlen, K., Pincus, R., Pohlmann, ., Pongratz, J., Rast, S., Schmidt, H., Schnur, R., Schulzweida, U., Six, K., Stevens, B., Voigt, A., and Roeckner, E.: MPI-M MPI-ESM1.2-LR model output prepared for CMIP6 ScenarioMIP ssp245, Earth System Grid Federation [data set], https://doi.org/10.22033/ESGF/CMIP6.6693, 2019a.

Wieners, K.-H., Giorgetta, M., Jungclaus, J., Reick, C., Esch, M., Bittner, M., Gayler, V., Haak, H., de Vrese, P., Raddatz, T., Mauritsen, T., von Storch, J.-S., Behrens, J., Brovkin, V., Claussen, M., Crueger, T., Fast, I., Fiedler, S., Hagemann, S., Hohenegger, C., Jahns, T., Kloster, S., Kinne, S., Lasslop, G., Kornblueh, L., Marotzke, J., Matei, D., Meraner, K., Mikolajewicz, U., Modali, K., Müller, W., Nabel, J., Notz, D., Peters-von Gehlen, K., Pincus, R., Pohlmann, H., Pongratz, J., Rast, S., Schmidt, H., Schnur, R., Schulzweida, U., Six, K., Stevens, B., Voigt, A., and Roeckner, E.: MPI-M MPI-ESM1.2-LR model output prepared for CMIP6 ScenarioMIP ssp585, Earth System Grid Federation [data set], https://doi.org/10.22033/ESGF/CMIP6.6705, 2019b.

Wunderling, N., Donges, J. F., Kurths, J., and Winkelmann, R.: Interacting tipping elements increase risk of climate domino effects under global warming, Earth Syst. Dynam., 12, 601-619, https://doi.org/10.5194/esd-12-601-2021, 2021.

Zanardo, S., Nicotina, L., Hilberts, A. G. J., and Jewson, S. P.: Modulation of economic losses from European floods by the North Atlantic Oscillation, Geophys. Res. Lett., 46, 2563-2572, https://doi.org/10.1029/2019GL081956, 2019.

Zelinka, M. D., Myers, T. A., McCoy, D. T., Po-Chedley, S., Caldwell, P. M., Ceppi, P., Klein, S. A., and Taylor, K. E.: Causes of higher climate sensitivity in CMIP6 models, Geophys. Res. Lett., 47, e2019GL085782, https://doi.org/10.1029/2019GL085782, 2020. 